\title{
Monomeric IgG Is Neuroprotective via Enhancing Microglial Recycling Endocytosis and TNF- $\alpha$
}

\author{
Raymond E. Hulse, Wade G. Swenson, Phillip E. Kunkler, David M. White, and Richard P. Kraig \\ Department of Neurology, The University of Chicago Medical Center, Chicago, Illinois 60637
}

In brain, monomeric immunoglobin $\mathrm{G}(\mathrm{IgG})$ is regarded as quiescent and only poised to initiate potentially injurious inflammatory reactions via immune complex formation associated with phagocytosis and tumor necrosis factor $\alpha$ (TNF- $\alpha$ ) production in response to disease. Using rat hippocampal slice and microglial cultures, here we show instead that physiological levels (i.e., $0.2-20 \mu \mathrm{g} / \mathrm{ml}$ ) of monomeric IgG unassociated with disease triggered benign low-level proinflammatory signaling that was neuroprotective against CA1 area excitotoxicity and followed a U-shaped or hormetic dose-response. The data indicate that physiological IgG levels activated microglia by enhancing recycling endocytosis plus TNF- $\alpha$ release from these cells to produce the neuroprotection. Minocycline, known for its anti-inflammatory and neuroprotective effects when given after disease onset, abrogated IgG-mediated neuroprotection and related microglial effects when given before injury. In contrast, E-prostanoid receptor subtype 2 (EP2) activation, which served as an exemplary paracrine stimulus like the one expected from neuronal activity, amplified IgG-mediated increased microglial recycling endocytosis and TNF- $\alpha$ production. Furthermore, like monomeric IgG these EP2 related effects took days to be effective, suggesting both were adaptive anabolic effects consistent with those seen from other long-term preconditioning stimuli requiring de novo protein synthesis. The data provide the first evidence that brain monomeric IgG at physiological levels can have signaling function via enhanced recycling endocytosis/TNF- $\alpha$ production from microglia unassociated with disease and that these IgG-mediated changes may be a means by which paracrine signaling from neuronal activity influences microglia to evoke neuroprotection. The data provide further support that low-level proinflammatory neural immune signaling unassociated with disease enhances brain function.

Key words: cytokine; slice cultures; neuroprotection; neuroinflammation; hippocampus; endocytosis; hormesis

\section{Introduction}

Immunoglobin $\mathrm{G}(\mathrm{IgG})$ is well recognized not only for its involvement in inflammatory reactions to neurological disease but also as an anti-inflammatory therapy to reduce brain disease (Fergusson et al., 2005; Arumugam et al., 2007). Monomeric IgG is a normal constituent of mammalian CSF (i.e., at $\sim 133 \mathrm{~nm}$ or 20 $\mu \mathrm{g} / \mathrm{ml})$ and so can be expected to be similarly present within brain interstitial space (Cserr, 1974). Its level there is orders of magnitude less than that of blood, where IgG emanates from B-cells (Lanzavecchia, 1983). The low level of IgG in brain suggests that IgG is restricted there, perhaps via high affinity neonatal Fc receptors localized to brain endothelial cells known to saturate at 10-1000 nм (Zhang and Pardridge, 2001), a range that

Received Aug. 13, 2008; accepted 0ct. 6, 2008.

This work was supported by grants from the National Institute of Neurological Disorders and Stroke (NS-19108) and American Heart Association, as well as by the White Foundation to R.P.K. R.E.H. was partially supported by National Institute of General Medical Science Training Grant T32-GM07839. W.G.S. was supported by the Dimensions Health Studies Program from Cornell College, Mount Vernon, lowa and the Brain Research Foundation. Marcia P. Kraig assisted in the preparation and maintenance of culture systems. We thank Heidi Mitchell for reading and commenting on a final version of this manuscript. Fast performance liquid chromatography was performed at the Center for Functional Genomics, The University of Albany, Albany, NY, and lgG measurements from CSF and media albumin measurements were performed at the Research Animal Diagnostic Laboratory, The University of Missouri, Columbia, MO

Correspondence should be addressed to Richard P. Kraig, Department of Neurology, MC2030, the University of Chicago Medical Center, 5841 South Maryland Avenue, Chicago, IL 60637. E-mail: rkraig@neurology.bsd.uchicago.edu.

DOI:10.1523/JNEUROSCI.3856-08.2008

Copyright $\odot 2008$ Society for Neuroscience 0270-6474/08/2812199-13\$15.00/0 includes physiological concentrations in brain. Conceivably, monomeric IgG exists in brain only as a quiescent signaling molecule prepared to initiate immune reactions via formation of immune complexes (Gessner et al., 1998; Nimmerjahn and Ravetch, 2006) in response to disease because it has no defined function in nondiseased brain.

However, monomeric IgG at levels physiological to the brain reacts specifically with its high affinity cognate receptor, Fc $\gamma$ RI, which is found on microglia, so-called immune cells of brain (Kennedy et al., 1980). Like their macrophage counterparts of the periphery, which completely recycle their surface membrane in little over $1 \mathrm{~h}$ (Mukherjee et al., 1997), microglia show a high degree of endocytosis. Evidence shows that monomeric IgG can signal via recycling endocytosis involving Fc $\gamma \mathrm{R} 1$ (Mellman et al., 1984; Harrison et al., 1994; Barnes et al., 2002). Furthermore, recycling endocytosis is used to shuttle proteins to the external milieu (Ang et al., 2004; Murray et al., 2005), and macrophages use this piggy-back transport format to release tumor necrosis factor $\alpha$ (TNF- $\alpha$ ) associated with phagocytosis (Murray et al., 2005), and so generate cytotoxic levels of this innate cytokine that can enhance disease severity (Barone et al., 1997; Zou and Crew, 2005).

In contrast, physiological TNF- $\alpha$ levels enhance synaptic transmission (Beattie et al., 2002) and enhanced synaptic transmission associated with learning is neuroprotective (Will et al., 2004). Accordingly, we used rat hippocampal slice cultures and 
primary microglia cultures to show that chronic (but not acute) treatment with monomeric IgG at physiological levels triggered neuroprotection against excitotoxic injury to CA1 pyramidal neurons via activation of microglia that includes enhanced recycling endocytosis and TNF- $\alpha$ release. Furthermore, abrogation of microglial activation using minocycline prevented IgG-based neuroprotection and microglial recycling endocytosis/TNF- $\alpha$ change. We also used E-prostanoid receptor subtype 2 (EP2) activation, as an exemplary paracrine signal from neural activity, to suggest that prostaglandin $\mathrm{E} 2\left(\mathrm{PGE}_{2}\right)$, released with increased pyramidal neuron activity, could amplify these newly defined monomeric IgG effects on microglial recycling endocytosis and TNF- $\alpha$. Together, the results show that microglial recycling endocytosis-associated TNF- $\alpha$ production and neuronal vitality (and perhaps activity) may be reciprocally connected via monomeric IgG trafficking. This work has appeared in preliminary form (Hulse et al., 2006; Kraig et al., 2007).

\section{Materials and Methods}

Determination of rat CSF IgG level. Adult rats $(n=5 ; 300-320 \mathrm{gm})$ were anesthetized with intraperitoneal pentobarbital $(50 \mathrm{mg} / \mathrm{kg})$ and placed in a standard stereotaxic unit. CSF $(\sim 60-100 \mu \mathrm{l} / \mathrm{animal})$ was withdrawn at the atlanto-occipital junction via a 26 gauge needle and tuberculin syringe mounted on a Narishige micromanipulator from a sterile exposure of the dorsal neck at the occiput-upper cervical spine. Samples were stored at $-80^{\circ} \mathrm{C}$ until quantification for $\mathrm{IgG}$ via microsphereimmunoassay. All experiments were approved by the Institutional Animal Care and Use Committee of the University of Chicago.

Culture preparation and maintenance. Slice cultures are widely accepted experimental models and were prepared as previously described (Kunkler and Kraig, 1997; Kunkler et al., 2004, 2005). However, after 4 d in vitro, they were transferred to a serum-free media to reduce potentially confounding effects of serum and allow study of IgG effects (see Results and supplemental materials, available at www.jneurosci.org). The serum-free media consisted of $96 \%$ Neurobasal (Invitrogen) supplemented to a total glucose concentration of $42 \mathrm{~mm}, 1 \mathrm{~mm}$ glutamine (Sigma), 2\% B27 supplement, $10 \mu \mathrm{g} / \mathrm{ml}$ gentamicin and $250 \mu \mathrm{g} / \mathrm{ml} \mathrm{Fun-}$ gizone (Invitrogen). Slice cultures were incubated at $36^{\circ} \mathrm{C}$ with $5 \% \mathrm{CO}_{2}$ balance air and media was changed twice a week. Slices were maintained 21-30 d in vitro before use.

Primary microglia cultures were prepared as previously described (Caggiano and Kraig, 1999) using Dulbecco's Modified Medium (\#D5976; Sigma) plus 10\% fetal bovine serum (\#10082-147; Invitrogen) and $10 \mu \mathrm{g} / \mathrm{ml}$ gentamicin (Invitrogen) (DMEM-10).

Experimental manipulations. We examined whether IgG could be neuroprotective by exposing slice cultures to nonspecific pooled rat IgG (\#012-000-003) or nonspecific pooled $\mathrm{F}\left(\mathrm{ab}^{\prime}\right)_{2}$ fragment (\#115-006003 ) in serum-free media (Jackson ImmunoResearch) for $3 \mathrm{~d}$. IgG doses were $0.2,2.0,20,200$ or $2000 \mu \mathrm{g} / \mathrm{ml}$ given for $3 \mathrm{~d}$ before and during injury (i.e., chronic exposure). The impact of acute exposure (i.e., $6 \mathrm{~h}$ before injury and immediately after injury) to $\operatorname{IgG}$ was also examined as well as prolonged exposure for $17 \mathrm{~d}$. Exposure to $\mathrm{F}\left(\mathrm{ab}^{\prime}\right)_{2}(3 \mathrm{~d})$ was performed at IgG doses $(0.2,2.0,20 \mu \mathrm{g} / \mathrm{ml})$ protective against excitotoxic injury. Serum-free media containing treatments were refreshed on the third day before injury inductions.

To discover whether immune complexes could influence potential effects from IgG, we exposed slice cultures for $3 \mathrm{~d}$ to immune complexes formed from equal volumes of chicken-ovalbumin $(2 \mu \mathrm{g} / \mathrm{ml}$, \#A2512; Sigma) and affinity purified rabbit anti-ovalbumin IgG $(40 \mu \mathrm{g} / \mathrm{ml}$, \#ROL-30A; Immunology Consultants Laboratory) mixed and incubated at $36^{\circ} \mathrm{C}$ for $30 \mathrm{~min}$ before use. Sodium azide was removed from rabbit anti-ovalbumin IgG via dialysis.

We tested whether IgG effects were related to TNF- $\alpha$ by use of soluble TNF receptor 1 (sTNFR1, $200 \mathrm{ng} / \mathrm{ml}$ \#425-R1-050; R \& D Systems) to abrogate TNF- $\alpha$ signaling. Recombinant rat TNF- $\alpha$ (\#510-RT; R \& D Systems) was applied to slice cultures $(100 \mathrm{pg} / \mathrm{ml})$ to mimic TNF- $\alpha$ se- cretion from IgG exposure. Minocycline (10 $\mu \mathrm{M}$, \#M9511; Sigma) was used to inhibit microglial activation (Lai and Todd, 2006).

Sham experiments consisted of heat-inactivated IgG, $\mathrm{F}\left(\mathrm{ab}^{\prime}\right)_{2}$ fragments or recombinant (i.e., sTNFR1 and TNF- $\alpha$ ) proteins [made by exposure to $95^{\circ} \mathrm{C}(10 \mathrm{~min})$ followed by ice $(10 \mathrm{~min}$ ) before use]. This was done to denature experimental proteins, and so remove their potential effects. However, production of recombinant proteins (i.e., TNF- $\alpha$ and sTNFR1 in experiments here) involved use of E. coli, which might contain endotoxin contamination (Gao and Tsan, 2003). The latter itself can have cellular and tissue affects (de Bock et al., 1998; Rosenzweig et al., 2004; Weissman and Welsh, 2004). This effect was not seen.

As noted above, we included specific treatments for $3 \mathrm{~d}$ before injury and during exposure to $N$-methyl-D aspartate (NMDA; \#454575; Cal Biochem) or oxygen-glucose deprivation (OGD) but not during subsequent maximal injury (see below). However, with this paradigm EP2mediated neuroprotection was so robust that it also markedly reduced maximal injury compared with other groups and so gave falsely elevated injury ratios. Accordingly, for experiments involving EP2-activation (see Fig. 8), treatments were continued for only $3 \mathrm{~d}$ and then excluded from injury and maximal injury exposures. Results for IgG between this and the former paradigm were comparable (see Figs. 1, 8). No treatments were included in either paradigm during maximal injury exposure.

Excitotoxic injury and quantification. Excitotoxic injury and quantification of slice culture CA1 area followed that reported by McCullough et al. (2004) with modifications described below. We used NMDA to trigger excitotoxic injury of CA1 area pyramidal neurons. Before NMDA exposure, slice cultures were screened for evidence of pyramidal area neuronal death by incubating cultures for $20 \mathrm{~min}$ in serum-free media containing Sytox Green (500 nM, \#S7020; Invitrogen). If CA1 pyramidal layer injury was seen (i.e., $>20$ Sytox positive cells), involved slice cultures were excluded; otherwise initial culture images were acquired (for background subtraction) using a Cool Snap $f x$ CCD camera (Photometrics) and MetaMorph (v. 7.0.4) software (Molecular Devices) on an inverted Leica DM-IRBE microscope (Leica Mikroskopie und Systeme). Slice cultures were then exposed to NMDA $(20 \mu \mathrm{M})$ in serum-free media for $60 \mathrm{~min}$ under normal incubation conditions (as defined above). After exposure the underside of each insert was rinsed by dipping it gently once each in three $60 \mathrm{~mm}$ dishes filled with $10 \mathrm{ml}$ of Neurobasal $\left(36^{\circ} \mathrm{C}\right)$ and then returned to the incubator in fresh serum-free media. Twenty-four hours later, injury was quantified by re-incubating slice cultures for $20 \mathrm{~min}$ in media containing Sytox Green and then acquiring images of injury. Finally, neuronal death in CA1 was maximized by overnight exposure to serum-free media containing $20 \mu \mathrm{M}$ NMDA. Final images were acquired after 20 min incubations in Sytox Green.

To further establish the applicability of slice culture excitotoxicity effects to the in vivo condition, we also used OGD to trigger CA1 area excitotoxic injury via methods that were modified from Newell et al. (1995). All cultures were prescreened to determine existing CA1 injury (i.e., $>20$ Sytox-positive cells in CA1 excluded) before exposure. The OGD chamber consisted of an airtight Plexiglas chamber $(47 \times 27 \times 22$ $\mathrm{cm}$ ) with controlled humidity (\#8534-025), temperature (\#8535-025), and $\mathrm{CO}_{2}$ (\#8528110; Coy Laboratory Products).

$\mathrm{O}_{2}$ levels were monitored with a USB-LS-450 Foxy $\mathrm{O}_{2}$ sensing probe (Ocean Optics). Two point calibrations [0\% and room air (i.e., $21 \% \mathrm{O}_{2}$ )] were performed at $36^{\circ} \mathrm{C}$ and $85 \%$ humidity for the $\mathrm{O}_{2}$ probe following the manufacturer's procedure before OGD. OGD consisted of placing slice culture inserts in a modified ischemic Ringer's solution (in mM): 33 sodium lactate, $75 \mathrm{KCl}, 17.9 \mathrm{NaHCO}_{3}, 0.1 \mathrm{CaCl}_{2}, 1.6 \mathrm{MgCl}_{2}$ (Bondarenko and Chesler, 2001). The sealed chamber was flushed with $\mathrm{N}_{2}(<1$ min) until $\mathrm{O}_{2}$ levels fell $<1 \%$ which was then changed to $85 \% \mathrm{~N}_{2}, 15 \%$ $\mathrm{CO}_{2}$ at $36^{\circ} \mathrm{C}$ and $85 \%$ humidity. $\mathrm{A} \mathrm{CO}_{2}$ percentage of $15 \%$ was chosen to acidify the ischemic Ringer's to pH 6.8 (Bondarenko and Chesler, 2001).

Slice cultures were exposed for $1 \mathrm{~h}$ to OGD, rinsed three times with 10 $\mathrm{ml}$ of Neurobasal $\left(36^{\circ} \mathrm{C}\right)$, returned to normoxic conditions in appropriate media (i.e., control or treated), and further processed as described for NMDA injury.

Calibration of the imaging system for NMDA and OGD consisted of setting the CCD camera to a uniform full image intensity (1000/4096) of the fluorescence in response to a fluorescein standard (\#F36915; Invitro- 
gen; 1:10 in PBS, $7.4 \mathrm{pH}$ ) imaged through a standard (100 $\mu \mathrm{m}$ deep) hemacytometer. For quantification of injury a stereotypic area-ofinterest (AOI) was drawn around CA1 for background, injury and maximized injury images and fluorescent values recorded. The average intensity ratio of the AOI was then used to define the relative degree of injury (i.e., injury/maximal injury), with background fluorescence subtracted from both values. Control culture injuries were measured with all experimental groups and adjusted to 1.00 with all related group injuries per experiment scaled proportionally for improved interexperiment comparisons between groups.

Immunohistochemistry. Immunohistochemistry for microglial activation parameters [CD11b and ED-1 (CD68)], markers for recycling endocytosis and early lysosomes [i.e., RAB11a and lysosomal-associated membrane protein 1 (LAMP1), respectively] followed standard procedures (Kunkler and Kraig, 1997) with modifications.

Slice cultures were fixed and sectioned as previously described (Kunkler et al., 2005). Sections $(20 \mu \mathrm{m})$ were processed for the microglial markers CD11b (directed against the CR3 receptor, \#MCA74G; Serotec) and ED-1 (CD68, \#MCA341R; Serotec) at 1:1000 dilutions, or the neuron-specific nuclear protein $(\mathrm{NeuN})$ at 1:1000 dilution (\#MAB377; Chemicon International), with all secondary antibodies used at 1:100 dilution and resultant immunostaining visualized via the diaminobenzidine reaction. Toluidine blue (\#T3260; Sigma) was used to increase contrast of the pyramidal cell layer.

Immunohistochemistry for the recycling endocytosis protein Rab11a (Murray et al., 2005) was completed using a method modified from Steiner and coworkers (Steiner et al., 2002). Microglia were fixed in PLP fixative ( $2 \%$ paraformaldehyde, $10 \mathrm{~mm} \mathrm{~L}$-sodium periodate, $75 \mathrm{~mm}$ L-lysine, and $37 \mathrm{~mm}$ phosphate buffer, $6.2 \mathrm{pH}$ ) or $4 \%$ paraformaldehydephosphate buffer $(7.3 \mathrm{pH})$ for $1 \mathrm{~h}$ at $4^{\circ} \mathrm{C}$. Cells were permeabilized in $0.04 \%$ digitonin (\#D141; Sigma) in PBS for $2.5 \mathrm{~min}$, blocked in 10\% BSA (\#A4503; Sigma) in PBS for $30 \mathrm{~min}$ at room temperature, and incubated overnight at $4^{\circ} \mathrm{C}$ with a monoclonal antibody directed against Rab11a (\#610656; BD Biosciences) at 1:200 in 3\% BSA-PBS. Cells were rinsed before incubation at room temperature in Alexa Fluor-594 conjugated goat anti-mouse secondary antibody (\#A11005; Invitrogen) at a 1:100 dilution in 3\% BSA-PBS for $1 \mathrm{~h}$. After rinsing, cells were mounted with Prolong Antifade (\#P7481; Invitrogen).

Immunohistochemistry for the lysosomal protein LAMP1 (Murray et al., 2005) was performed using a method modified from Lewis and coworkers (Lewis et al., 1985). After fixation, primary microglia were immersed in methanol at $-20^{\circ} \mathrm{C}$ for $10 \mathrm{~s}$ and then placed in a $0.1 \%$ solution of $\mathrm{NaBH}_{4}$ (\#S-9125; Sigma) in PBS for $10 \mathrm{~min}$ at room temperature to quench free aldehydes. Cells were then incubated overnight at $4^{\circ} \mathrm{C}$ in a monoclonal antibody directed against LAMP1 (\#428017; Calbiochem) at 1:300 in 3\% BSA-PBS. Microglia were rinsed, incubated in goat antimouse secondary antibody conjugated to Alexa-Fluor 594 (1:100) and mounted as described above for RAB 11a. The specificity of all immunoreactions was demonstrated by lack of staining from omission of primary antibodies.

Endocytosis. We used $20 \mathrm{~nm}$ carboxylate modified latex spheres (\#F8787; Invitrogen) to determine the rate of endocytosis in primary microglia. After coincubation of spheres with treatments for specific times, microglia were fixed in PLP fixative or $4 \%$ paraformaldehydephosphate buffer $(7.3 \mathrm{pH})$ at $4^{\circ} \mathrm{C}$ overnight and mounted with Prolong Antifade (Invitrogen).

Microscopic image quantifications. We quantitated immunohistochemistry and endocytosis blinded to conditions and via 3-10 random, noncontiguous full CCD camera fields obtained from microscopic images (derived from at least 3 biological replicates) using digital image analysis strategies. Furthermore, all cells within a microscopic field were counted to reduce sampling bias (Burbach et al., 2004), a strategy we also applied to specific-cell enhanced sampling for cytokine mRNA expression of TNF- $\alpha$ (see supplemental materials, available at www.jneurosci. org). For CD11b and CD68, color images were acquired from the basilar pyramidal neuron CA1 area (from 3 to 5 slice cultures per experimental group) with a Hitachi HV-C20A 3 CCD camera and LaborLux D microscope (Leica) at a total magnification of $31 \times\left(\right.$ i.e., $5.65 \times 10^{3} \mu \mathrm{m}^{2}$ ). Cell body area (CD11b) and number of ED-1 positive cells (CD68) were measured using Image Pro Plus (v. 4.1) software (Media Cybernetics), using single-plane stereological approach where cells that reached image margins were counted only on the right, and lower limits and images were noncontiguous (Howard and Reed, 1998).

A similar quantification strategy was applied to fluorescence intensity of particle endocytosis and RAB 11a and LAMP1 immunostaining. Fluorescence intensity (i.e., average fluorescence intensity/fluorescence area) was registered for endocytosis, RAB11a, and LAMP1 using a Cool Snap $f x$ CCD and MetaMorph software on an inverted DM-IRBE or LaborLux D microscope (Leica) with total magnification of $31 \times$ or $25 \times$ (i.e., $4.56 \times 10^{3} \mu \mathrm{m}^{2}$ ), respectively.

Before acquisitions, the imaging system was calibrated to register uniform full image intensity (2000/4096) to a fluorescein standard (488 nm excitation). Images were acquired at either $488 \mathrm{~nm}$ excitation (endocytosis) or $594 \mathrm{~nm}$ excitation (RAB11a and LAMP1). We used a confocal microscope (Leica SP2 AOBS) to create representative images of IgGinduced changes in primary microglial endocytosis and RAB11a plus LAMP1 staining (see below). Images were flattened from $\mathrm{z}$-stacks made from 30 to 60 image planes taken every $1-2 \mu \mathrm{m}$.

Fast performance liquid chromatography. Fast performance liquid chromatography was used to confirm the absence of immune complexes (i.e., protein components above a monomeric IgG molecular weight of $\sim 150 \mathrm{kDa}$ ) (Dorrington and Tanford, 1970) derived from IgG in media containing IgG, immune complexes, or related heat-inactivated sham proteins and controls (Diemel et al., 2005). An Äkta Explorer fast performance liquid chromatography system (GE Healthcare) was used with a Superose 6HR 10/30 column (molecular separation range 5-5000K kDa) and UV detector $(280 \mathrm{~nm})$ with molecular weight standards.

TNF- $\alpha$ assay. For tissue TNF- $\alpha$ levels, we dissected the CA1 area from slice cultures submerged in cold $\left(4^{\circ} \mathrm{C}\right) \mathrm{PBS}$ and stored samples at $-80^{\circ} \mathrm{C}$ until homogenization. We determined sample total protein using $\mathrm{Mi}$ croBCA assay (\#23235; Pierce). TNF- $\alpha$ levels were determined using a single-plex microsphere-based flow cytometric immunoassay for rat TNF- $\alpha$ (\#X80000001T; Bio-Rad) (Hulse et al., 2004; Kunkler et al., 2004). Media for TNF- $\alpha$ assay was stored at $-80^{\circ} \mathrm{C}$ until assayed similarly.

Cellular identification of TNF- $\alpha$ change from noninjurious brain activation. We used standard electrophysiological procedures coupled to novel laser dissection microscopy and real-time RT-PCR to probe for specific brain cell enhanced TNF- $\alpha$ changes from noninjurious activation of brain tissue via spreading depression. Detailed methods are given in supplemental materials, available at www.jneurosci.org.

Statistics and figure preparation. We analyzed data per Sigma Stat (v. 3.5) software (Systat Software). All data passed normality testing ( $p$ value to reject: 0.05 ) and equal variance testing ( $p$ value to reject: 0.05 ). Control data per experiment were set to 1.00 with related group results scaled proportionally to facilitate interexperiment interpretations. ANOVA using Holm Sidak post hoc testing was used for data analyses for Figures 1-5 and ANOVA for data analyses of Figures $6-8$. Significance was defined as $<0.05$. CorelDraw (v. $\times 3$; Corel) and Photoshop (v. CS2; Adobe) were used to compose figures.

\section{Results}

\section{Culture IgG levels}

We sought to explore whether physiological levels of monomeric IgG can have signaling function in noninjured brain. We have previously grown slice cultures in media containing 23\% horse serum (Kunkler and Kraig, 1997; Kunkler et al., 2004, 2005). However, this translates to $335(2 \mu \mathrm{M}) \mu \mathrm{g} / \mathrm{ml}$ IgG because $15 \%$ of the albumin plus globulin total $(60 \mathrm{mg} / \mathrm{ml})$ is IgG (Invitrogen) and its use here would preclude delineation of effects from lower IgG levels. Accordingly, we used slice cultures maintained in serum-free media, where the content and therefore the effect of IgG could be isolated. In addition, potentially confounding effects of serum would be avoided.

We anticipated that if physiological effects of IgG were found, they would be seen $\sim 20 \mu \mathrm{g} / \mathrm{ml}$. This hypothesis stems from the fact that mammalian (i.e., as measured in dog, man, monkey, 
horse, and swine) CSF IgG is normally $10-13 \mu \mathrm{g} / \mathrm{ml}$ (Spector, 1956; Wurster and Haas, 1994) and CSF constituents fairly estimate comparable constituent levels in brain interstitial space (Cserr, 1974). However, rat CSF IgG levels have not been reported, prompting us to determine that adult rat (296-308 gm; $n=5$ ) CSF contains $16 \pm 2 \mu \mathrm{g} / \mathrm{ml}$ (or $107 \mathrm{nM}$ ). Furthermore, albumin is often included with use of such low-level proteins to maintain bioactivity by preventing adsorption to plastic ware. However, albumin is already included in Neurobasal (B27) media (Brewer et al., 1993) although its actual level is not listed. Accordingly, we measured the albumin level in our media and found it to be $\sim 2.3 \mathrm{mg} / \mathrm{ml}$. Thus, albumin is present in Neurobasal (B27) media far in excess of IgG (i.e., 144:1 ratio) consistent with the excess seen in normal CSF (i.e., 500-1000:1 ratio) (Spector, 1956; Wurster and Haas, 1994).

Microglial cultures (i.e., > 99\% microglia) deteriorate, and so initially become reactive, under serum-free conditions. Accordingly, microglial cultures were maintained in media with $10 \%$ fetal bovine serum. This corresponds to 5 ( $30 \mathrm{~nm}) \mu \mathrm{g} / \mathrm{ml}$ IgG because $2 \%$ of the albumin plus globulin total $(24 \mathrm{mg} / \mathrm{ml})$ is IgG (Invitrogen). Thus, increments of added IgG were comparable with those of slice cultures (except at 0.2 and $2.0 \mu \mathrm{g} / \mathrm{ml}$ added $\mathrm{IgG}$ where they corresponded to 5.2 and $7.0 \mu \mathrm{g} / \mathrm{ml}$, respectively).

\section{Characterization of slice cultures in serum-free media}

We characterized slice cultures grown in serum-free media to confirm that they were comparable with those previously grown in horse serum-based media. Briefly, slice cultures prepared and used in serum-free media cultures were not only comparable with those from serum-based media, but they showed improved physiological function (e.g., could trigger spreading depression for the first time from a single electrical pulse, a level of excitability seen in vivo). The characterization is detailed in supplemental Methods (available at www.jneurosci.org as supplemented material).

\section{IgG-induced neuroprotection in slice cultures}

We used NMDA mediated excitotoxicity to model neurodegenerative diseases, including ischemia, that mainly affect CA1 pyramidal neurons, whereas OGD was used as a confirmatory in vitro model for injury from ischemia (Newell et al., 1995). Pooled, nonspecific IgG triggered U-shaped neuroprotective responses (Fig. 1). Over the dose range $0.2,2.0,20,200,2000 \mu \mathrm{g} / \mathrm{ml}$ IgG, pretreat-

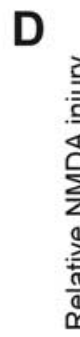
$\left({ }^{*} p<0.05\right)$.
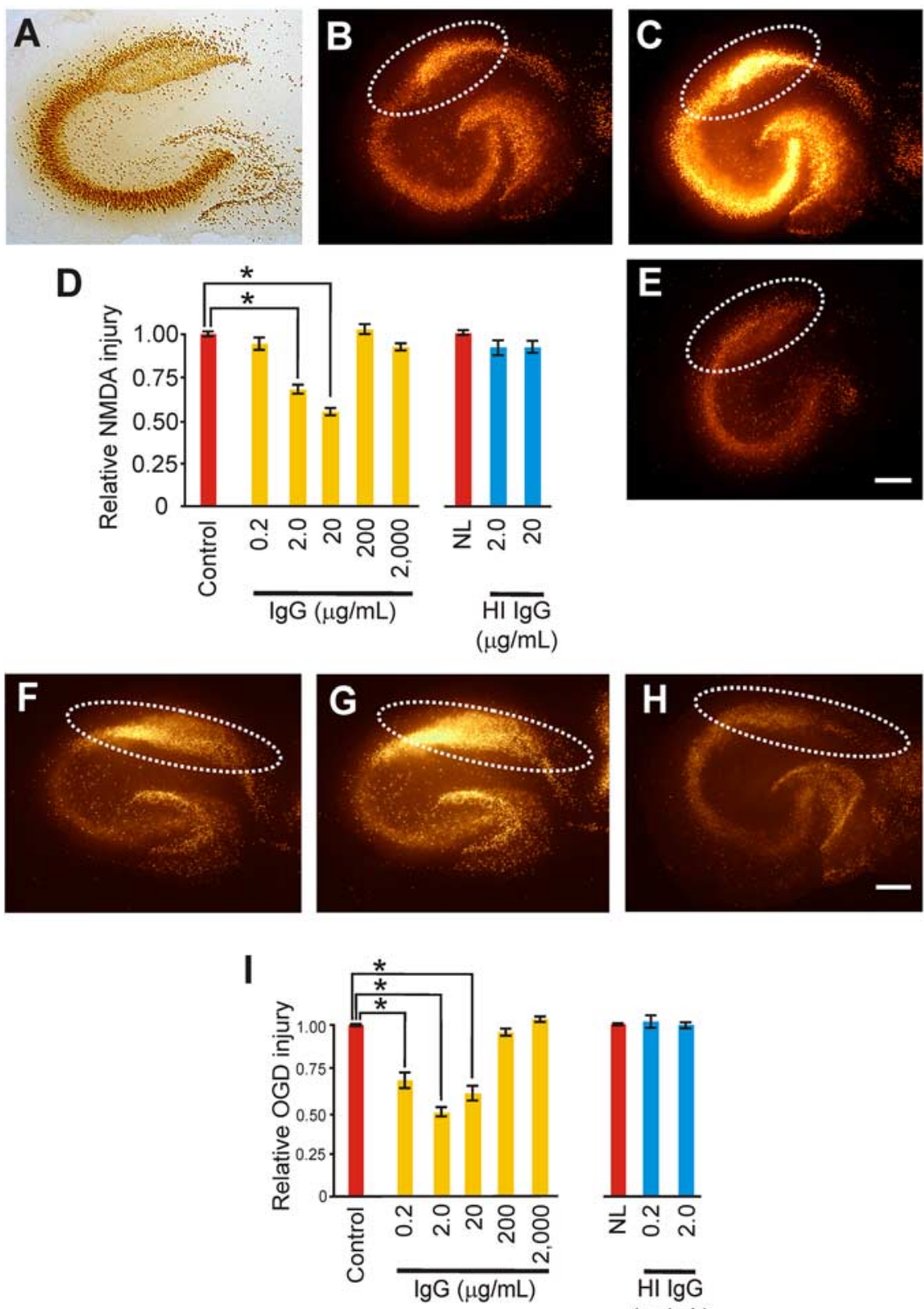

$(\mu \mathrm{g} / \mathrm{mL})$

Figure 1. IgG-triggered neuroprotection against excitotoxic injury showed a U-shaped response in slice cultures. $A$, Immunostaining with NeuN shows the principal neuron cytoarchitecture for the pyramidal and dentate gyrus areas. $\boldsymbol{B}-\boldsymbol{D}$, Excitotoxicinjury from NMDA was measured via Sytox, a fluorescent dead cell marker, quantified in the CA1 area (dotted white lines), and expressed as a ratio of injury $(\boldsymbol{B})$ over maximal injury ( $($ ) made relative to control cultures (D). $\boldsymbol{E}$, Exposure to nonspecific, monomeric $\lg G$ for 3 d evoked significant $(p<$ $0.001 ; \alpha=1.00$ ) reductions in injury at 2.0 and 20 (shown) $\mu \mathrm{g} / \mathrm{ml}$ [ with relative injury levels of $0.89 \pm 0.06(n=13), 0.67 \pm 0.04(n=$ 13), $0.55 \pm 0.05(n=13), 1.04 \pm 0.06(n=21)$ and $0.92 \pm 0.04(n=20)$ vs control $(1.00+0.03 ; n=28)]$. Heat-inactivated $(\mathrm{HH}) \lg \mathrm{gG}$ $(2.0 \mathrm{and} 20 \mu \mathrm{g} / \mathrm{ml}$ ) had no protective effect against NMDA [with p equal to 0.58 (differences in means) and relative injury levels of $0.92 \pm$ 0.07 ( $n=11)$ and $0.92 \pm 0.07(n=27)$ vs control $(1.00 \pm 0.03 ; n=21)$. Similarly, monomeric lgG-triggered neuroprotection against OGD-induced excitotoxic injury showed a similar U-shaped response in slice cultures. $F, G, I$, Excitotoxic injury from OGD exposure was measured and quantified as above in the $C A 1$ area (dotted white lines) and expressed as a ratio of injury $(\boldsymbol{F})$ over maximal injury $(\boldsymbol{G})$ made relative to control cultures $(\boldsymbol{I})$. $\boldsymbol{H}, \boldsymbol{I}$, Exposure to nonspecific, monomeric $\operatorname{lgG}$ for $3 \mathrm{~d}(\boldsymbol{H})$ evoked significant $(p<0.001 ; \alpha=1.00$ ) reductions in injury at $0.2,2.0$ (shown) and $20(I) \mu \mathrm{g} / \mathrm{ml}$ but not 200 and $2000 \mu \mathrm{g} / \mathrm{ml}$ [with relative injury levels of $0.68 \pm 0.09(n=8)$, $0.49 \pm 0.05(n=11), 0.0 .59 \pm 0.08(n=10), 0.95 \pm 0.05(n=6)$, and $1.02 \pm 0.04(n=6)$ vs control $(1.00 \pm 0.02 ; n=11)]$. HII $\lg \mathrm{G}$ $(0.2$ and $2.0 \mu \mathrm{g} / \mathrm{ml})$ had no protective effect against $0 \mathrm{GD}$ [with $p=1.00$ (differences in means) with relative injury levels of $1.03 \pm 0.06$ $(n=15), 1.00 \pm 0.04(n=15)$ vs control $(1.00 \pm 0.06 ; n=6)]$. Scale bars, $250 \mu \mathrm{m}$. Data represent mean \pm SEM and significance

ment produced significant neuroprotection at 2.0 and $20 \mu \mathrm{g} / \mathrm{ml}$ but not at other doses against NMDA injury. Similarly, IgG pretreatment evoked significant neuroprotective effects against OGD at 0.2, 2.0 and $20 \mu \mathrm{g} / \mathrm{ml}$ but not at 200 and $2000 \mu \mathrm{g} / \mathrm{ml}$. 

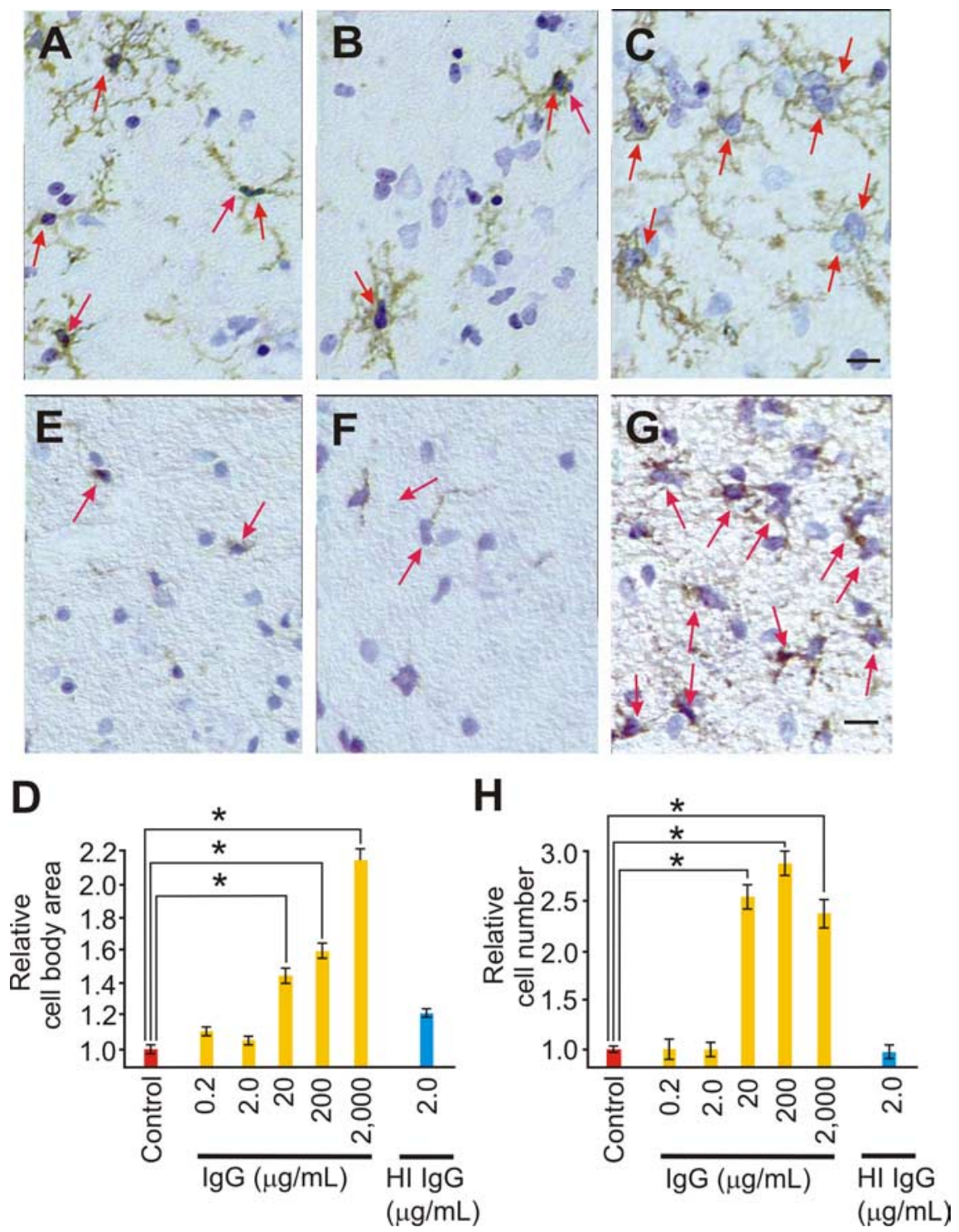

Figure 2. IgG evoked a nonlinear, progressive activation of slice culture microglia. $\boldsymbol{A}-\boldsymbol{D}$, Immunostaining images for CD11b, counterstained with toluidine blue, are shown under control conditions $(\boldsymbol{A})$ or after $3 \mathrm{~d}$ of $\mathrm{lgG}[2.0 \mu \mathrm{g} / \mathrm{ml}(\boldsymbol{B})$ and $2000 \mu \mathrm{g} / \mathrm{ml}$ (C)] and quantified $(\boldsymbol{D})$ as cell body area (red arrows), a morphological marker for microglia activation, relative to control. Control immunostaining $(\boldsymbol{A})$ shows typical ramified microglial morphology with evenly but sparingly spaced cells. Three day exposure to low $[0.2$ and $2.0(\boldsymbol{B}) \mu \mathrm{g} / \mathrm{ml}] \mathrm{lgG}$ had no impact on microglial cell body area, whereas 20,200 , and $2000(\boldsymbol{C}) \mu \mathrm{g} / \mathrm{ml} \mathrm{prompted} \mathrm{a}$ significant ( $p<0.001 ; \alpha=1.00$ ) increase $(\boldsymbol{D})$ in cell body area, a process that includes addition of internal membrane to the cell surface. Heat inactivation (H) of $\mathrm{lgG}(2.0 \mu \mathrm{g} / \mathrm{ml})$ had no effect on cell body area [with relative microglial sizes of $1.05 \pm 0.05$, $1.19 \pm 0.05,1.43 \pm 0.10,1.57 \pm 0.10,2.14 \pm 0.19$ and $1.00 \pm 0.05$ vs control $(1.00 \pm 0.05 ; n=18$ cells from $\geq 3$ slice cultures/group)]. $\boldsymbol{E}-\boldsymbol{H}$, Immunostaining for ED-1, a marker for late endosomes or early lysosomes; thus, when increased, microglial activation followed a similar nonlinear pattern from lgG. ED-1 positive cells (red arrows) are shown under control conditions $(\boldsymbol{E})$ or after $3 \mathrm{~d}$ of $\mathrm{lgG}[2.0 \mu \mathrm{g} / \mathrm{ml}(\boldsymbol{F})$ and $2000 \mu \mathrm{g} / \mathrm{ml}(\boldsymbol{G})]$ and quantified $(\boldsymbol{H})$ as relative cell number from control. Low-dose lgG $(0.2$ and $2.0 \mu \mathrm{g} / \mathrm{ml})$ had no effect on cell number, but higher doses $[20,200$, and $2000(\boldsymbol{G}) \mu \mathrm{g} / \mathrm{ml}]$ evoked a significant $(p<$ $0.001 ; \alpha=1.00)$ increase in positive cell number. $\mathrm{HI} \mathrm{lgG}(2.0 \mu \mathrm{g} / \mathrm{ml})$ had no effect on ED-1 positive cell number [with relative number of ED-1 positive cells of $0.95 \pm 0.13,1.00 \pm 0.13,2.54 \pm 0.24,2.85 \pm 0.24,2.36 \pm 0.38$ and $0.98 \pm 0.20$ vs control (1.00 $\pm 0.07 ; n=6$ image fields from $\geq 3$ slice cultures/group)]. Scale bars, $25 \mu \mathrm{m}$. Images were taken from basilar CA1 dendritic area. Data represent mean \pm SEM and significance $\left({ }^{*} p<0.05\right)$.

We next showed that intact IgG was required for neuroprotection (Fig. 1). IgG heat inactivation at exemplary doses that otherwise would reduce NMDA-mediated injury now had no influence over injury severity. Similarly, heat inactivation of $\operatorname{IgG}$ doses that otherwise would be protective against OGD were not protective. Incubations with the $\mathrm{F}\left(\mathrm{ab}^{\prime}\right)_{2}$ portion of pooled $\operatorname{IgG}$ at the same doses ( $n=6$ /group) also failed to elicit neuroprotection $[p=0.57$ differences in means; $\alpha=0.05$ with injury levels of $1.08 \pm 0.01,1.04 \pm$ $0.03,1.02 \pm 0.04,1.04 \pm 0.021 .02 \pm 0.04$ versus control $(1.00 \pm 0.05)]$.

Immune complex formation might account for neuroprotection from IgG because immune complexes are a common means of IgG-mediated signal transduction (Kennedy et al., 1980; Gessner et al., 1998). Accordingly, we applied immune complexes formed from monomeric IgG $(20 \mu \mathrm{g} / \mathrm{ml})$ to slice cultures for $3 \mathrm{~d}$. This failed to produce neuroprotection, as did application of heat-inactivated immune complexes (also made from $20 \mu \mathrm{g} / \mathrm{ml} \operatorname{IgG}$ ) $[p=0.89$ difference in means; $\alpha=0.05$ with injury levels, respectively $(n=$ $6 /$ group), of $1.03 \pm 0.03,1.03 \pm 0.07$ compared with control $(1.00 \pm 0.04)]$.

We used fast performance liquid chromatography to confirm the absence of immune complexes [i.e., defined as elements with a molecular weight far beyond the molecular weight $(\sim 150 \mathrm{kDA})]$ of $\mathrm{IgG})$ (Dorrington and Tanford, 1970) in both freshly prepared serum-free media [containing $0.2,2.0,20.200$ and $2000 \mu \mathrm{g} / \mathrm{ml}$ $\operatorname{IgG}(n=2$ /group $)]$ and analogous media aged for $3 \mathrm{~d}$ with slice cultures. Occasional samples (i.e., one of two samples at 0.2, 2.0 and $2000 \mu \mathrm{g} / \mathrm{ml}$ ) registered elements consistent with IgG dimers (i.e., molecular weight $\sim 300 \mathrm{kDA}$ ). Finally, fast performance liquid chromatography confirmed the presence of immune complexes in media freshly prepared with their addition but demonstrated their absence by $3 \mathrm{~d}$ after incubation with slice cultures (data not shown).

We used $3 \mathrm{~d} \operatorname{IgG}$ applications because, if neuroprotective, we reasoned an IgGmediated effect might be consistent with other delayed preconditioning stimuli, which require at least a day to develop and require de novo protein synthesis (Kariko et al., 2004). In fact, acute application (i.e., immediately after excitotoxic injury) of IgG $(20 \mu \mathrm{g} / \mathrm{ml})$ or its heat-inactivated form was not protective against NMDA injury ( $p=0.190$ difference in means) with injury levels of $1.00 \pm 0.04(n=9)$ and $0.89 \pm 0.04(n=6)$, respectively, versus control [1.00 $\pm 0.04(n=9)]$. Alternatively, prolonged applications of $\operatorname{IgG}$ (i.e., for the $17 \mathrm{~d}$ slice cultures matured in serum-free media) also showed a significant $(p<0.001 ; \alpha=1.00)$ enhanced $U$-shaped neuroprotective response and shifted its maximum to the left. In addition, high dose IgG $(2000 \mu \mathrm{g} / \mathrm{ml})$ significantly $(p<0.001 ; \alpha=1.00)$ increased injury. Relative levels of injury over the dose range were $0.39 \pm 0.07(n=9), 0.56 \pm 0.05(n=5), 0.74 \pm 0.02(n=$ $7), 0.94 \pm 0.03(n=5)$ and $1.38 \pm 0.12(n=5)$ versus control $[1.00 \pm 0.08(n=9)]$. Furthermore, IgG treatment $(20 \mu \mathrm{g} / \mathrm{ml})$ 
for $6 \mathrm{~h}$ did not trigger neuroprotection against NMDA exposure or OGD $(p=$ $0.19 ; \alpha=0.14$ and $p=0.25 ; 0.10$, respectively) with relative injury levels of $0.93 \pm 0.04(n=9)$ versus control $[1.00 \pm 0.03(n=6)]$ and $0.97 \pm 0.02$ $(n=9)$ versus control [1.00 $\pm 0.04(n=$ $6)$ ], respectively. TNF- $\alpha$ expression was significantly elevated $(p<0.001 ; \alpha=$ $1.00)$ over control at $6 \mathrm{~h}$ of IgG treatment $(20 \mu \mathrm{g} / \mathrm{ml})$ with relative levels of $3.53 \pm$ $0.05(n=13)$ and $1.00 \pm 0.16(n=13)$, which is consistent with the rapid expression after stimulation of this cytokine (Lee et al., 1993; Mascher et al., 1999).

\section{Microglial activation with}

\section{IgG-mediated neuroprotection}

IgG (i.e., Fc) receptors are expressed on microglia (in contrast to neurons, astrocytes or oligodendrocytes) in normal brain (Kennedy et al., 1980). Thus, we asked whether IgG-based neuroprotection involved microglial activation (Fig. 2). Three day exposures to IgG evoked a nonlinear, progressive increase in microglial cell body size (a change that denotes microglial activation to a "primed" state (Streit, 1995), shown via CD11b immunostaining). Specifically, IgG triggered a significant increase in cell size (compared with control slice cultures) at 20, 200, and $2000 \mu \mathrm{g} / \mathrm{ml}$, whereas heat-inactivated IgG $(2.0 \mu \mathrm{g} / \mathrm{ml})$, 0.2 and $2.0 \mu \mathrm{g} / \mathrm{ml}$ IgG had no effect. Immunostaining for ED-1 (CD68), an endosomal/lysosomal marker (Bauer et al., 1994) that also reflects microglial activation (Streit, 1995), showed a similar nonlinear, progressive activation by IgG. Here, IgG triggered a significant increase in positive cell number at 20, 200 and 2000 $\mu \mathrm{g} / \mathrm{ml}$ whereas $0.2,2.0 \mu \mathrm{g} / \mathrm{ml} \operatorname{IgG}$ and heat-inactivated IgG $(2.0 \mu \mathrm{g} / \mathrm{ml})$ had no effect. Thus, these markers of reactive microglial change did not parallel the $\mathrm{U}$-shaped neuroprotective responses seen over the IgG dose range.

Monomeric IgG binds selectively to the high affinity $\mathrm{Fc}$ receptor, $\mathrm{Fc} \gamma \mathrm{R} 1$, at neuroprotective IgG levels (Mellman et al., 1984; Harrison et al., 1994; Gessner et al., 1998; Barnes et al., 2002; Nimmerjahn et al., 2006;) and might consequently influence microglial recycling endocytosis because ligand-receptor interactions are commonly followed by surface membrane trafficking that includes recycling endocytosis (Gáborik and Hunyady, 2004; Maxfield and McGraw, 2004). Use of microglia in primary culture confirmed this hypothesis (Fig. 3). As a screening test, we examined endocytotic uptake of $20 \mathrm{~nm}$ fluorescent beads. Twenty minutes is sufficient time for recycling endocytosis to reach a steady-state (Mukherjee et al., 1997), and this period of IgG exposure was
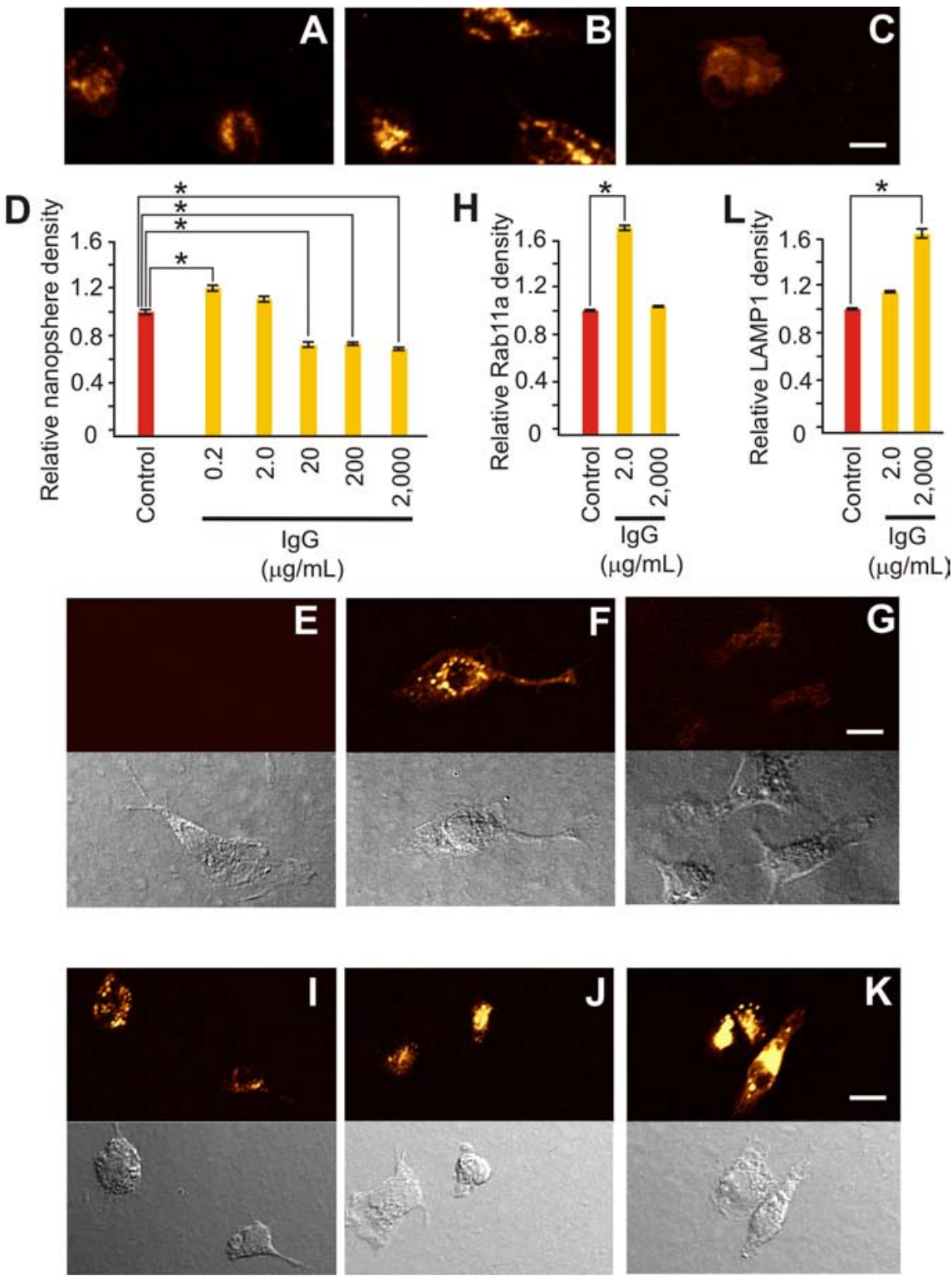

Figure 3. Neuroprotective levels of $\mathrm{lg} G$ selectively increased primary microglial recycling endocytosis. $\boldsymbol{A}-\boldsymbol{D}$, Endocytosis of 20 $\mathrm{nm}$ fluorescent beads for $20 \mathrm{~min}$ is shown under control conditions $(\boldsymbol{A})$ and after inclusion of lgG $[2.0 \mu \mathrm{g} / \mathrm{ml}(\boldsymbol{B})$ or $2000 \mu \mathrm{g} / \mathrm{ml}$ $(\boldsymbol{C})$ ] and was quantified $(\boldsymbol{D})$ as relative fluorescence density compared with control. Low $(0.2 \mu \mathrm{g} / \mathrm{ml}) \mathrm{lgG}$ triggered a significant $(p<0.001 ; \alpha=1.00)$ increase in endocytosis, whereas $2.0 \mu \mathrm{g} / \mathrm{ml}$ had no effect, and higher doses $(20,200$, and $2000 \mu \mathrm{g} / \mathrm{ml})$ triggered significant $(p<0.001 ; \alpha=1.00)$ decreases [with relative levels of $1.20 \pm 0.04(n=131$ cells), $1.10 \pm 0.05(n=72)$, $0.68 \pm 0.04(n=70), 0.72 \pm 0.02(n=112)$ and $0.67 \pm 0.02(n=114)$ versus control $(1.00+0.04 ; n=107)]$. Immunostaining for specific endosomal subtypes ( $\boldsymbol{E}-\boldsymbol{G}$ and $\boldsymbol{I}-\boldsymbol{K}$, with related phase contrast images shown immediately below) parallel this U-shaped impact of monomeric lgG on endocytosis. $\boldsymbol{E}-\boldsymbol{H}$, RAB11a immunostaining, a marker for recycling endocytosis, showed a significant increase ( $p<0.001 ; \alpha=1.00$ ) from control $(\boldsymbol{E})$ only at the neuroprotective lgG dose of $2.0 \mu \mathrm{g} / \mathrm{ml}(\boldsymbol{F})$ and not at $2000 \mu \mathrm{g} / \mathrm{ml}(\boldsymbol{G})$ (or in the absence of added lgG control), with measurements quantified as relative fluorescence intensity compared with control $(\boldsymbol{H})$. [Respective relative levels were $1.68 \pm 0.12$ ( $n=111$ cells) and $1.00 \pm 0.04$ ( $n=104)$ versus (control 1.00 $\pm 0.04 ; n=92$ )]. $I-L$, LAMP1 immunostaining, a specific marker for late endosomes or early lysosomes, showed a rise from control $(\boldsymbol{I})$ after $2.0 \mu \mathrm{g} / \mathrm{ml}(\boldsymbol{J})$ that became significantly $(p<0.001 ; \alpha=1.00)$ greater than control at $2000(\boldsymbol{K}) \mu \mathrm{g} / \mathrm{ml}$ $\lg G[$ with $(\boldsymbol{L})$ relative levels of $1.13 \pm 0.05(n=135)$ and $1.65 \pm 0.14(n=124)$ vs control $(1.00 \pm 0.05 ; n=105)]$. Scale bars, $10 \mu \mathrm{m}$. Data represent mean \pm SEM and significance $\left({ }^{*} p<0.05\right)$.

sufficient to trigger a significant increase in uptake of beads at 0.2 $\mu \mathrm{g} / \mathrm{ml}$, no change at $2.0 \mu \mathrm{g} / \mathrm{ml}$, and significant decreases in uptake at 20,200, $2000 \mu \mathrm{g} / \mathrm{ml}$. Although significantly increased uptake at $0.2 \mu \mathrm{g} / \mathrm{ml} \mathrm{IgG}$ begins to be consistent with the U-shaped IgG-neuroprotective response, the basis for the progressive decrease in uptake from $2.0-2000 \mu \mathrm{g} / \mathrm{ml}$ is unclear. Nanometer beads may not selectively reflect recycling endocytosis for a host 
of reasons including changes in vesicle $\mathrm{pH}$ (Mukherjee et al., 1997) and related processing via lysosomes. This could quench bead fluorescence and so falsely indicate a drop in uptake. Thus, we proceeded to immunostaining to detect potential changes in specific endocytotic vesicle trafficking. We used immunostaining for RAB11a, specific for recycling endocytosis (Ang et al., 2004; Murray et al., 2005), to probe for changes in microglial recycling endocytosis from $\operatorname{IgG}$, and found it to be significantly enhanced at 2.0 but not $2000 \mu \mathrm{g} / \mathrm{ml}$. Immunostaining for LAMP1, specific for late endosomes/early lysosomes (Murray et al., 2005), showed no significant increase at $2.0 \mu \mathrm{g} / \mathrm{ml}$ but a significant increase at $2000 \mu \mathrm{g} / \mathrm{ml}$. Although this is the normal path followed by immune complexes taken up by macrophages (Ukkonen et al., 1986), perhaps high dose monomeric IgG, consistent with that seen with other high level ligand-receptor interactions (Pandey, 2005), promotes lysosome trafficking.

\section{TNF- $\alpha$ involvement in IgG mediated recycling endocytosis and neuroprotection}

Macrophage surface membrane cusps involved with phagocytosis are the sites from which vesicular membrane trafficking from the Golgi (Ang et al., 2004; Murray et al., 2005) carrying TNF- $\alpha$ release the cytokine to the external milieu (Murray et al., 2005). Furthermore, although most often associated with injury, evidence exists to indicate that TNF- $\alpha$ also can be neuroprotective. Thus, we tested whether microglia, a myeloid cell related to macrophages (Streit, 1995), might also release TNF- $\alpha$ in response to $\operatorname{IgG}$ ( $3 \mathrm{~d}$ exposure) and whether this release could account for the neuroprotection seen from IgG (Fig. 4). We found that IgG triggered significant increases in TNF- $\alpha$ expression in primary microglia and slice cultures that resembled U-shaped dose-response curves. For comparisons, maximal TNF- $\alpha$ levels were $891 \pm 97 \mathrm{pg} / \mathrm{ml}$ for microglia $(20 \mu \mathrm{g} / \mathrm{ml} \operatorname{IgG})$ and $1048 \pm 98$ $\mathrm{pg} / \mathrm{mg}$ for slice cultures $(20 \mu \mathrm{g} / \mathrm{ml} \operatorname{IgG})$, levels seen with noninjurious activation of brain tissue (Kunkler et al., 2004) and previously used by Wilde and coworkers (2000) in vitro with serumfree media to evoke neuroprotection in slice cultures. We speculate the significant drop in TNF- $\alpha$ at $0.2 \mu \mathrm{g} / \mathrm{ml} \operatorname{IgG}$ (and to a lesser extent $2.0 \mu \mathrm{g} / \mathrm{ml} \operatorname{IgG}$ ) may be attributable to a concomitant greater increased expression of TNF receptor 1 or sTNFR 1 by TNF- $\alpha$ (Oppenheim and Feldmann, 2001) at this dose. This follows from the fact that TNF- $\alpha$ stimulates expression of TNFR1 (both soluble and membrane bound forms) and the $\mathrm{K}_{\mathrm{d}}$ for TNFR1 is 0.1-1.0 nM (Oppenheim and Feldmann, 2001).

Next, we confirmed that IgG-based neuroprotection requires TNF- $\alpha$ (Fig. 4). Three day treatment with $100 \mathrm{pg} / \mathrm{ml}$ TNF- $\alpha$ significantly reduced NMDA injury, thus mimicking neuroprotection from IgG. Heat inactivation of TNF- $\alpha$ removed the neuroprotective effect. Furthermore, treatment with previously neuroprotective $\operatorname{IgG}(20 \mu \mathrm{g} / \mathrm{ml})$ that also contained $200 \mathrm{ng} / \mathrm{ml}$ sTNFR1 (to abrogate TNF- $\alpha$ signaling) removed neuroprotection.

IgG-mediated neuroprotection from OGD also requires TNF- $\alpha$. Three day treatment with $100 \mathrm{pg} / \mathrm{ml}$ TNF- $\alpha$ significantly reduced injury from OGD (Fig. 4) and resembled the degree of protection seen from monomeric IgG. Treatment with previously neuroprotective $2.0 \mu \mathrm{g} / \mathrm{ml} \operatorname{IgG}$ that also contained sTNFR1 $(200 \mathrm{ng} / \mathrm{ml})$ removed neuroprotection.

Microglia are the principal source of TNF- $\alpha$ in brain associated with irreversible injury such as that seen with ischemic brain injury (Gregersen et al., 2000). However, whether these cells are also the main source of TNF- $\alpha$ after noninjurious brain activation is uncertain. Cytokine mRNA is faithfully processed to re-
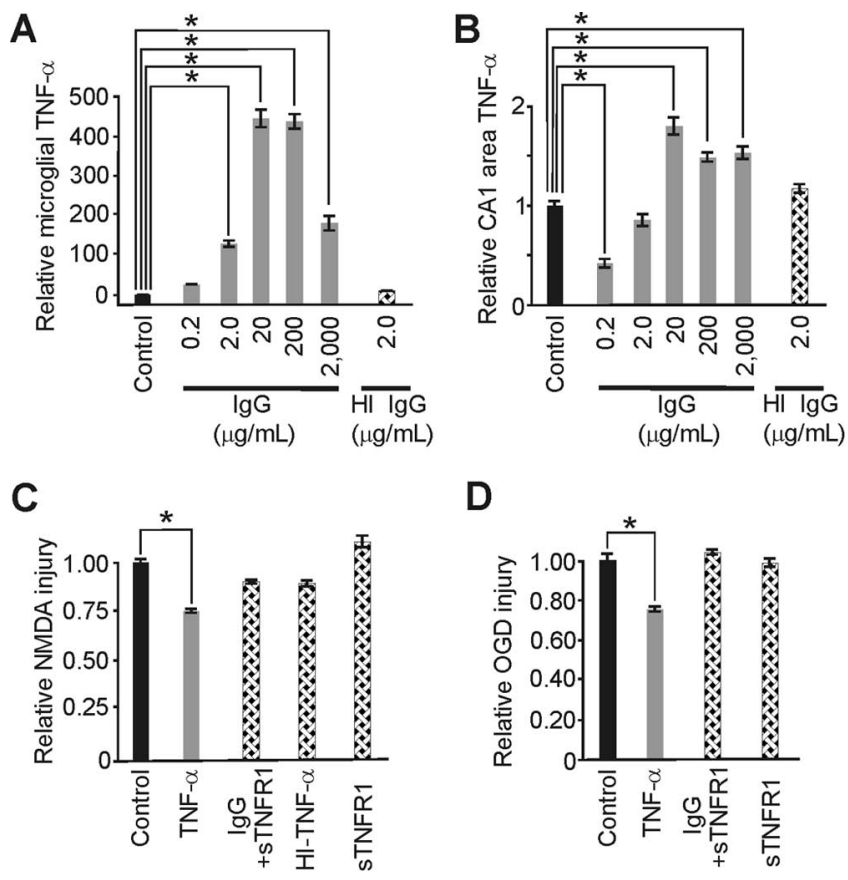

Figure 4. IgG-based neuroprotection from excitotoxic injury involved microglial TNF- $\alpha$. $\boldsymbol{A}$, IgG elevated TNF- $\alpha$ at $0.2 \mu \mathrm{g} / \mathrm{ml}$ and triggered significant $(p<0.001 ; \alpha=1.00$ ) U-shaped increases in TNF- $\alpha$ from primary microglia over the remaining dose range [but heat inactivation (HI) of $\mathrm{lgG}(2.0 \mu \mathrm{g} / \mathrm{ml})$ had no effect] [with respective relative levels of $29 \pm 0.2,123 \pm 14$, $445 \pm 48,436 \pm 41,175 \pm 39$ and $11 \pm 0.4$ compared with (control $1.00 \pm 0.2 ; n=$ $6 /$ group]. $B$, Slice culture TNF- $\alpha$ responses to increasing $\lg \mathrm{G}$, although similar, also showed a significant ( $p<0.002 ; \alpha=1.00$ ) drop from control at $0.2 \mu \mathrm{g} / \mathrm{ml} \mathrm{lgG} \mathrm{(perhaps} \mathrm{because} \mathrm{of} \mathrm{a}$ disproportionately increased TNF receptor expression at this dose) and significant ( $p<0.001$; $\alpha=1.00)$ increases at 20,200 , and $2000 \mu \mathrm{g} / \mathrm{ml}$. HI of neuroprotective $\operatorname{lgG}(2.0 \mu \mathrm{g} / \mathrm{ml})$ had no effect on slice culture TNF- $\alpha$ [with respective relative levels of $0.41 \pm 0.10,0.83 \pm 0.12$, $1.77 \pm 0.16,1.45 \pm 0.09,1.53 \pm 0.11,1.30 \pm 0.06$ ( $n=5 /$ group) vs control $(1.00 \pm 0.10$; $n=20)$ ]. C, Notably, TNF- $\alpha$ pretreatment alone for $3 \mathrm{~d}$ mimicked lgG-based significant ( $p<$ $0.001 ; \alpha=1.00$ ) neuroprotection from NMDA. Removal of TNF- $\alpha$ signaling via coapplication of soluble TNF receptor 1 (sTNFR1) abrogated neuroprotection from an otherwise neuroprotective $\operatorname{lgG}$ dose $(20 \mu \mathrm{g} / \mathrm{ml})$ as did HI of TNF- $\alpha(100 \mathrm{pg} / \mathrm{ml})$, as did treatment with sTNFR1 alone [with respective relative injury levels of $0.75 \pm 0.02(n=12), 0.90 \pm 0.03(n=6), 0.89 \pm$ $0.03(n=6)$, and $1.14 \pm 0.06(n=12)$ compared with control $(1.00 \pm 0.04 ; n=21)] . \boldsymbol{D}$, Similar significant ( $p<0.001 ; \alpha=0.99$ ) protective effects from TNF- $\alpha$ treatment were seen with excitotoxic injury from $0 G D$ and abrogation of protection at $2.0 \mu \mathrm{g} / \mathrm{ml} \mathrm{lgG}$ with inclusion of sTNFR1. [Respective relative injury levels were $0.74 \pm 0.03(n=18), 1.05 \pm 0.06(n=14)$ and $0.98 \pm 0.04(n=15)$ compared with control $(1.00 \pm 0.05 ; n=24)]$. Data represent mean \pm SEM and significance $\left({ }^{*} p<0.05\right)$.

lated protein expression (Oppenheim and Feldmann, 2001). Accordingly, we used laser dissection microscopy coupled with realtime RT-PCR to determine whether microglia preferentially trigger brain production of TNF- $\alpha$ after spreading depression, a robust but noninjurious perturbation of brain (Nedergaard and Hansen, 1988; Kunkler et al., 2004) known to rapidly trigger increased production of TNF- $\alpha$ (Kunkler et al., 2004). We examined spreading depression because unlike long-term potentiation evoked from a stimulating electrode, spreading depression uniformly activates involved neural tissue. This lessens the likelihood for sampling errors resulting from harvesting cells from nonactivated brain. One hour of recurrent spreading depression triggered a preferential and significant elevation of TNF- $\alpha$ mRNA in microglia compared with astrocytes or neurons (Fig. 5). Because cytokines can be low expression species, we also simultaneously monitored interleukin-1 $\beta$ to further establish that microglia can be the main source of so-called "effector" innate cytokines (Op- 
penheim and Feldmann, 2001) with noninjurious activation of brain (Fig. 5). Our results showed that interleukin- $1 \beta$ mRNA also preferentially rose in microglia $1 \mathrm{~h}$ after $1 \mathrm{~h}$ of spreading depression.

\section{Minocycline prevents IgG- neuroprotection and microglial activation}

Minocycline increases neuronal survival when administered after the onset of excitotoxic injury (Tikka et al., 2001) and abrogates microglial activation (Tikka et al., 2001; Lai and Todd, 2006). Accordingly, we administered minocycline $(10 \mu \mathrm{M})$ with IgG to slice cultures for $3 \mathrm{~d}$ and confirmed that it prevented IgG-induced neuroprotection against both NMDA and OGD (Fig. 6). With NMDA, pretreatment with 2.0 and $20 \mu \mathrm{g} / \mathrm{ml} \mathrm{IgG} \mathrm{was} \mathrm{neuropro-}$ tective (Fig. 1) but no significant protection occurred (over the range 0.2, 2.0, 20, 200 , and $2000, \mu \mathrm{g} / \mathrm{ml} \mathrm{IgG)}$ with inclusion of minocycline. Also, minocycline pretreatment alone had no impact on injury severity. Similarly, although $0.2,2.0$ and 20 $\mu \mathrm{g} / \mathrm{ml}$ IgG alone were protective against OGD (Fig. 1), no significant neuroprotection was evident when minocycline was included. Minocycline alone had no impact on OGD injury severity.

Twenty minute minocycline $(10 \mu \mathrm{M})$ exposure was also sufficient to prevent increased endocytosis as well as increased recycling endocytosis at IgGneuroprotective doses (Fig. 7). At 0.2 $\mu \mathrm{g} / \mathrm{ml}$ IgG, minocycline abrogated the previously seen significant increase in endocytosis (Fig. 3) and lowered endocytosis seen at $2.0 \mu \mathrm{g} / \mathrm{ml}$ to a significant decline.

Minocycline had no impact on reductions in IgG-induced endocytosis (Fig. 3) seen at 20-2000 $\mu \mathrm{g} / \mathrm{ml}$ IgG, which remained significantly lower than control. Also, minocycline changed the significant increase in recycling endocytosis that was previously seen (Fig. 3) at $2.0 \mu \mathrm{g} / \mathrm{ml}$ IgG to a significant decrease (Fig. 7). However, minocycline amplified recycling endocytosis at 2000 $\mu \mathrm{g} / \mathrm{ml}$ from a nonsignificant relative level of 1.00 (Fig. 3) to a significant level of 3.17. Similarly, minocycline amplified the significant level of lysosomes seen at $2000 \mu \mathrm{g} / \mathrm{ml} \mathrm{IgG} \mathrm{from} 1.65$ (Fig. 3) to 3.16 without a significant change at $2.0 \mu \mathrm{g} / \mathrm{ml}$ (Fig. 7).

Three day minocycline $(10 \mu \mathrm{M})$ exposures also changed TNF- $\alpha$ release levels in response to IgG in both primary microglia and slice cultures (Fig. 7). Although IgG responses in primary microglia remained significantly greater than control and retained the U-shaped response, they were significantly less than that seen from IgG alone (Fig. 3) from 2.0-2000 $\mu \mathrm{g} / \mathrm{ml} \mathrm{IgG.}$ Minocycline had an even greater inhibition of TNF- $\alpha$ production from IgG in slice cultures (Fig. 7). Furthermore, whereas minocycline alone did not affect primary microglial production of TNF- $\alpha$, it significantly inhibited TNF- $\alpha$ production in slice cultures.

These results show that minocycline stopped microglial increased recycling endocytosis and abrogated neuroprotec- tion from a physiological level of IgG (i.e., $0.2-20 \mu \mathrm{g} / \mathrm{ml}$ ). Minocycline also prevented the related increased TNF- $\alpha$ release in slice cultures at this neuroprotective dose. These findings further support the suggestion that physiologically activated microglia (i.e., to a primed state) protect neurons (Streit, 2002). Minocycline also amplified levels of recycling endocytosis and lysosomal vesicles at $2000 \mu \mathrm{g} / \mathrm{ml}$ without associated increased TNF- $\alpha$ expression. Thus, endosomal vesicle trafficking can be dissociated from TNF- $\alpha$ production/ release in microglia by pharmacological maneuvers, high ligand [i.e., IgG (Fig. 3)] levels or their amplification via EP2activation (see below).

\section{Prostaglandin enhances microglial recycling endocytosis} Finally, because microglia affect neurons via IgG-induced recycling endocytosis and TNF- $\alpha$, we asked whether neurons might affect these microglial processes. If so, monomeric IgG might reciprocally couple normal neuronal and microglial functions.

We focused to EP2-activation using Butaprost, an agonist for this receptor, as an exemplary paracrine signal of neuronal activity for several reasons. First, EP2-activation using Butaprost is neuroprotective (McCullough et al., 2004). Second, EP2 receptors are found on microglia (Caggiano and Kraig, 1999). Third, 


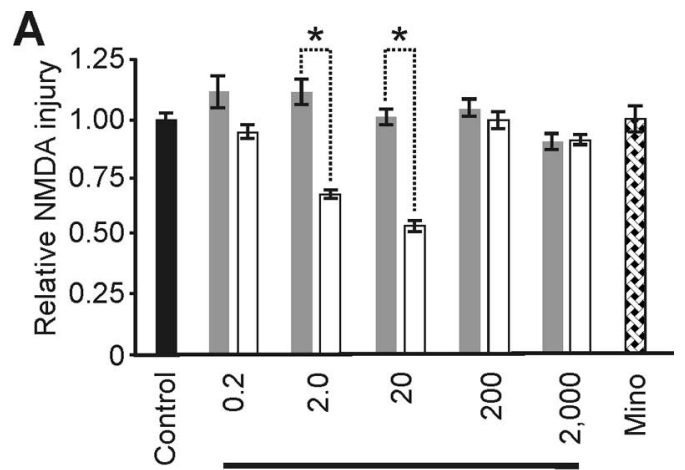

$\lg G(\mu \mathrm{g} / \mathrm{mL})+\min o$

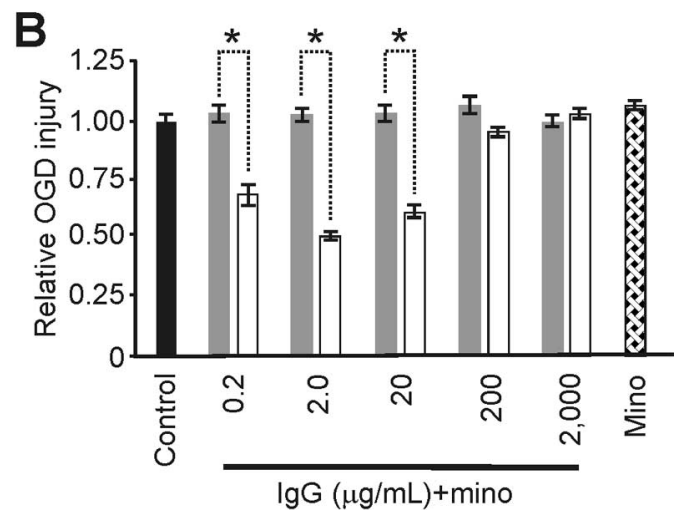

Figure 6. Minocycline abrogated IgG-based neuroprotection from excitotoxic injury. $\boldsymbol{A}$, Injury from NMDA: minocycline (mino) pretreatment (gray) significantly removed the neuroprotective effect of 2.0 and $20 \mu \mathrm{g} / \mathrm{ml} \operatorname{lgG}(p<0.002 ; \alpha=1.00)$ and had no impact from control on the severity of excitotoxic injury from NMDA when used alone. For comparison, respective injury levels without minocycline (white) from Figure 1 are shown. [Respective relative injury levels over the full dose range were $(n=23 /$ group) $1.12 \pm 0.10,1.10 \pm 0.10,1.1 .01 \pm 0.06$, $1.02 \pm 0.06,1.00 \pm 0.06$ and $1.01 \pm 0.10$ versus control $(1.00 \pm 0.03 ; n=13)]$. $\boldsymbol{B}$, Injury from OGD: minocycline (mino) pretreatment (gray) had no impact on injury severity from OGD and significantly removed the neuroprotective effects otherwise seen from $0.2,2.0$, and 20 $\mu \mathrm{g} / \mathrm{ml} \operatorname{lgG}(p<0.001 ; \alpha=1.00)$. [Respective relative injury levels over the full dose range were ( $n=15$ /group) $1.05 \pm 0.04,1.03 \pm 0.04,1.04 \pm 0.07,1.08 \pm 0.07,0.98 \pm 0.06$ and $1.09 \pm 0.04$ vs control $(1.00 \pm 0.03 ; n=12$ /group) $]$. Data represent mean \pm SEM and significance $\left({ }^{*} p<0.05\right)$.

$\mathrm{PGE}_{2}$, which activates EP2 receptors in vivo, is increased with neuronal activity (Yamagata et al., 1993). Fourth, $\mathrm{PGE}_{2}$ amplifies endocytosis in macrophages and so might have a similar effect on microglia (Wainszelbaum et al., 2006).

Three day exposure of primary microglia to $\operatorname{IgG}(20 \mu \mathrm{g} / \mathrm{ml})$ with or without EP2-activation (using $10 \mathrm{~nm}$ Butaprost) was used to determine whether EP2-activation augmented effects seen with IgG alone (Fig. 8). Brief 20 min exposures [like that which could initiate increased endocytosis and recycling endocytosis from IgG (Fig. 3)] did not evoke an amplification of responses to EP2-activation. For example, relative fluorescence of nanosphere endocytosis for $2.0 \mu \mathrm{g} / \mathrm{ml} \mathrm{IgG+EP2-activation} \mathrm{and} \mathrm{EP2-}$ activation were $1.20 \pm 0.05(n=87)$ and $1.24 \pm 0.08(n=92)$ whereas those for RAB11a immunostaining were $1.57 \pm 0.04$ $(n=84)$ and $1.61 \pm 0.10(n=68)$ and with associated $P$ values of 0.571 and 0.662 , respectively. However, three day exposures triggered significant amplifications. First, the latter confirmed a significant increase in endocytosis for IgG and IgG plus EP2activation but not EP2-activation alone. Furthermore, EP2activation and IgG coincubation significantly increased endocytosis over that seen with IgG alone. Second, three day exposures triggered a significant increase in recycling endocytosis for IgG and IgG plus EP2-activation but not EP2-activation alone. Again, coincubation of EP2-activation with IgG significantly increased recycling endocytosis over that seen with IgG alone. Third, IgG alone triggered a nonsignificant increase in early lysosomes, which became significant when IgG was coincubated with EP2-activation, and returned to a nonsignificant elevation with EP2-activation. EP2-activation also amplified the IgG-induced TNF- $\alpha$ change in primary microglia (Fig. 8). Three day exposure to IgG and IgG plus EP2-activation triggered significantly increased expression of TNF- $\alpha$, whereas EP2 activation alone had no effect. Coincubation with EP2-activation and IgG significantly increased TNF- $\alpha$ over that seen with IgG alone.

Finally in light of the above results and because EP2-activation reduces excitotoxic injury (McCullough et al., 2004), we reasoned the EP2-activation neuroprotection might involve TNF- $\alpha$. Thus, we removed the latter signaling via inclusion of sTNFR1 (Fig. 8) with EP2-activation. EP2-activation for $3 \mathrm{~d}$ triggered a significant reduction in injury from NMDA as expected, but coincubation with sTNFR1 removed this protective effect, a level of injury that was comparable with controls and significantly greater than with EP2-activation alone.

\section{Discussion}

The present findings show that in the brain monomeric IgG is not simply a quiescent immuno protein poised to become active via immune complex formation associated with disease. Instead, monomeric IgG at physiological levels increases resilience of brain against excitotoxic injury in a U-shaped dose-response. This IgG-based neuroprotection involves similar U-shaped microglial activation responses that include increased recycling endocytosis and TNF- $\alpha$ production, two previously unrelated microglial functions that are amplified by EP2-activation.

Proinflammatory immune signaling is increasingly recognized as a concomitant of normal brain function. Major histocompatability complex expression, which traditionally is known for its involvement in antigen presentation within the immune system, is upregulated during neural development and by activity-dependent synaptic plasticity (Huh et al., 2000; Boulanger and Shatz, 2004). TNF- $\alpha$, also recognized for its involvement in synaptic plasticity (see below), increases major histocompatability complex expression (Neumann et al., 1997). Furthermore, reactive (to a primed state) microglia are involved in neurogenesis and spatial learning in adults (Ziv et al., 2006). Monomeric IgG can now be included in this same benign context.

Considerations of brain IgG signaling have previously focused on its role in cross-linking Fc receptors via immune complex reactions associated with disease. Such cross-linking activates low (Fc $\gamma$ RII and Fc $\gamma$ RIII) and high (Fc $\gamma \mathrm{RI})$ affinity receptors which leads to inflammatory changes that include phagocytosis and TNF- $\alpha$ production in immune cells (Stuart and Ezekowitz, 2005). However, immune complex reactions cannot explain IgGbased neuroprotection as IgG applications did not contain immune complexes, and when specifically applied, immune complexes did not evoke neuroprotection. In contrast, Fc $\gamma \mathrm{RI}$ receptors found specifically on the microglial subtype of brain cells (Kennedy et al., 1980) bind monomeric IgG with high affinity and resultantly have signaling function via recycling endocytosis (Mellman et al., 1984; Harrison et al., 1994; Barnes et al., 2002). Recent evidence shows membrane trafficking from phagocytosis prompts TNF- $\alpha$ release from macrophages (Murray et al., 2005). Our results extend this finding from macrophage phago- 
cytosis associated with disease to the benign process of microglial recycling endocytosis related to monomeric IgG, which might function as a parsimonious link between neuronal activity and TNF- $\alpha$ release in normal brain.

Evidence also supports involvement of the innate cytokine, TNF- $\alpha$, in normal brain function. Beattie and coworkers (2002) show that TNF- $\alpha$, released from glia, enhances synaptic efficacy by increasing AMPA ( $\alpha$-amino-3-hydroxy-5methyl-4-isoxazolepropionic acid) receptors in cultured neurons. Stellwagen and Malenka (2006) went on to show that glial TNF- $\alpha$ also drives increased expression of AMPA receptors as a synaptic scaling response to activity deprivation from tetrodotoxin. Importantly, such AMPA receptor expression increases are also seen after long-term potentiation, a well accepted cellular model of learning (Park et al., 2004). Furthermore, environmental enrichment, which results in increased hippocampal learning and is neuroprotective (Will et al., 2004), triggers increased expression of AMPA receptor expression (Naka et al., 2005), which involves increased expression of TNF- $\alpha$. Thus, although TNF- $\alpha$ is not a requisite for longterm potentiation (Kaneko et al., 2008), it is involved in activity-dependent neuroprotection that results from long-term potentiation (Kraig et al., 2006) and spreading depression (Kraig et al., 2005) and it is also elevated by environmental enrichment (Kraig et al., 2003). Although TNF- $\alpha$ release conceivably can come from neurons or glia (Beattie et al., 2002; Stellwagen and Malenka, 2006), our studies focused to its release from microglia because these cells are the principal source of TNF- $\alpha$ in activated brain in vivo (Gregersen et al., 2000) after brain injury. In addition, monomeric IgG reacts specifically with this brain cell subtype under conditions unassociated with injury but whether microglia are the main source of TNF- $\alpha$ under such conditions is unknown. Accordingly, we showed that after noninjurious activation of brain from spreading depression (Nedergaard and Hansen, 1988; Kunkler et al., 2004, 2005) TNF- $\alpha$ also emanates from microglia. Attempts to confirm that long-term potentiation also triggered TNF- $\alpha$ production restricted to microglia have thus far been unsuccessful. We suspect this is caused by sampling difficulties associated with the small region activated by electrical stimulation. Nonetheless, this published literature and our results here begin to suggest that recycling endocytosis of IgG might be a means to coordinate changes in synaptic activity with $\mathrm{TNF}-\alpha$ production from microglia.

To begin exploring a potential link between neuronal activity and microglial recycling endocytosis, TNF- $\alpha$ production plus related neuroprotection, we tested whether paracrine signaling proportionate to synaptic activity could amplify these IgG-
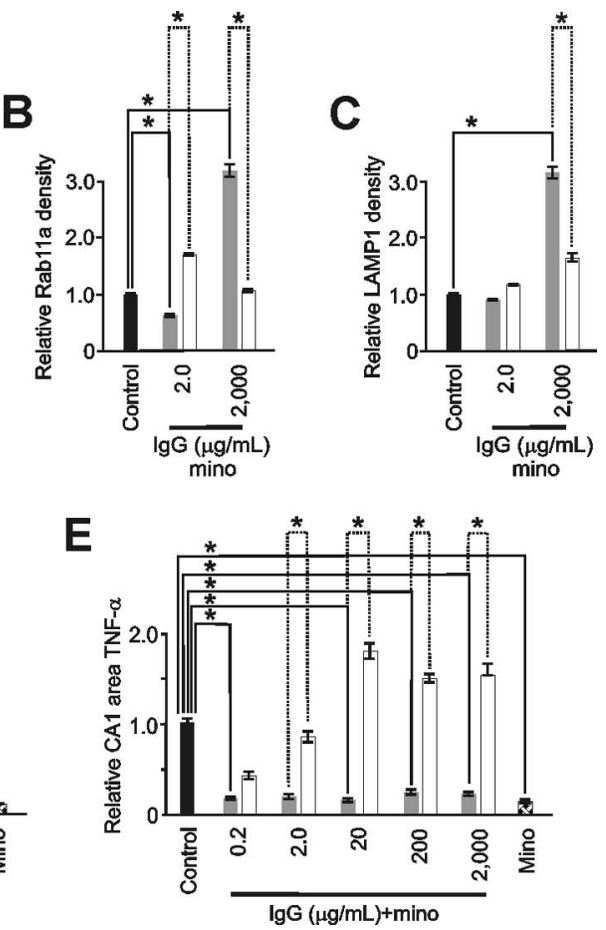

Figure 7. Minocycline abrogated microglial changes induced by neuroprotective levels of $\lg G$. $A-C$, Minocycline (mino) pretreatment (gray) significantly abrogated nanosphere endocytosis $(\boldsymbol{A})$ at 0.2 and $2.0 \mu \mathrm{g} / \mathrm{ml} \mathrm{lgG}(p<0.001 ; \alpha=1.00)$. Mino(20) $-2000 \mu \mathrm{g} / \mathrm{ml}$ ) and had no impact alone on nanosphere uptake. Similarly $(\boldsymbol{B})$, minocycline significantly abrogated the increased lgG-mediated recycling endocytosis evidenced by RAB11a immunostaining at $2.0 \mu \mathrm{g} / \mathrm{ml} \mathrm{lgG} \mathrm{but} \mathrm{in} \mathrm{contrast} \mathrm{signifi-}$ ( expression of TNF- $\alpha$ indicating that minocycline could differentially impact endosomal trafficking and otherwise related TNF- $\alpha$ production. For example, minocycline pretreatment (gray) reduced lgG-mediated changes in TNF- $\alpha$ (white) from microglia (D) and the $C A 1$ area of slice cultures $(\boldsymbol{E})$. In primary microglia, these reductions were significant $(p<0.001 ; \alpha=1.00)$ at $20-2000$

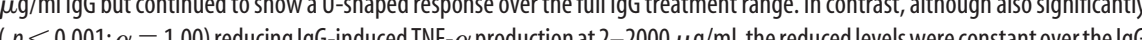
treatment range. Furthermore, minocycline alone significantly $(p<0.001 ; \alpha=1.00)$ reduced TNF- $\alpha$ production in slice cultures but not primary microglia. [Specific relative levels were $(\boldsymbol{A}) 0.94 \pm 0.04$ ( $n=110$ cells), $0.77 \pm 0.04(n=98), 0.72 \pm$ $0.02(n=98), 0.63 \pm 0.02(n=110), 0.63 \pm 0.02(n=112)$ and $0.89 \pm 0.04(n=182$ cells $)$ vs control $(1.00 \pm 0.04 ; n=107)$

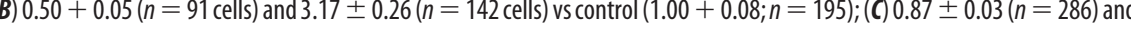
0.20 vs control $(1.00 \pm 0.10)$ and all groups $n=6$ culture dishes per group; $(\boldsymbol{E}) 0.16 \pm 0.03(n=10), 0.18 \pm 0.07(n=7)$ $0.14 \pm 0.04(n=9), 0.23 \pm 0.07(n=12), 0.22 \pm 0.07(n=12)$, and $0.13 \pm 0.04(n=13)$ vs control $(1.00 \pm 0.10 ; n=20$ slices per group)]. Data represent mean \pm SEM and significance $\left({ }^{*} p<0.05\right)$.

mediated effects. We chose $\mathrm{PGE}_{2}$ as an exemplary paracrine signal because its release to interstitial space is directly related to neuronal activity (Yamagata et al., 1993). $\mathrm{PGE}_{2}$ acts via four E-prostanoid receptors, with the $\mathrm{EP} 2$ receptor isoform expressed on microglia (Caggiano and Kraig, 1999) and its activation via the selective agonist Butaprost is known to be neuroprotective (McCullough et al., 2004). EP2 receptors are also found on neurons, which was the focus of McCullough and coworkers (2004) who concluded that Butaprost's neuroprotective effects were caused by this neural cell type. Although our results cannot exclude neuronal involvement, they extend considerations of EP2-activation to amplification of adaptive IgG-mediated microglial changes of recycling endocytosis and TNF- $\alpha$ production as well as related neuroprotection. Furthermore, the results indicate that microglial recycling endocytosis and related TNF- $\alpha$ production can be modulated by paracrine signals, which may include those from neuronal activity. 

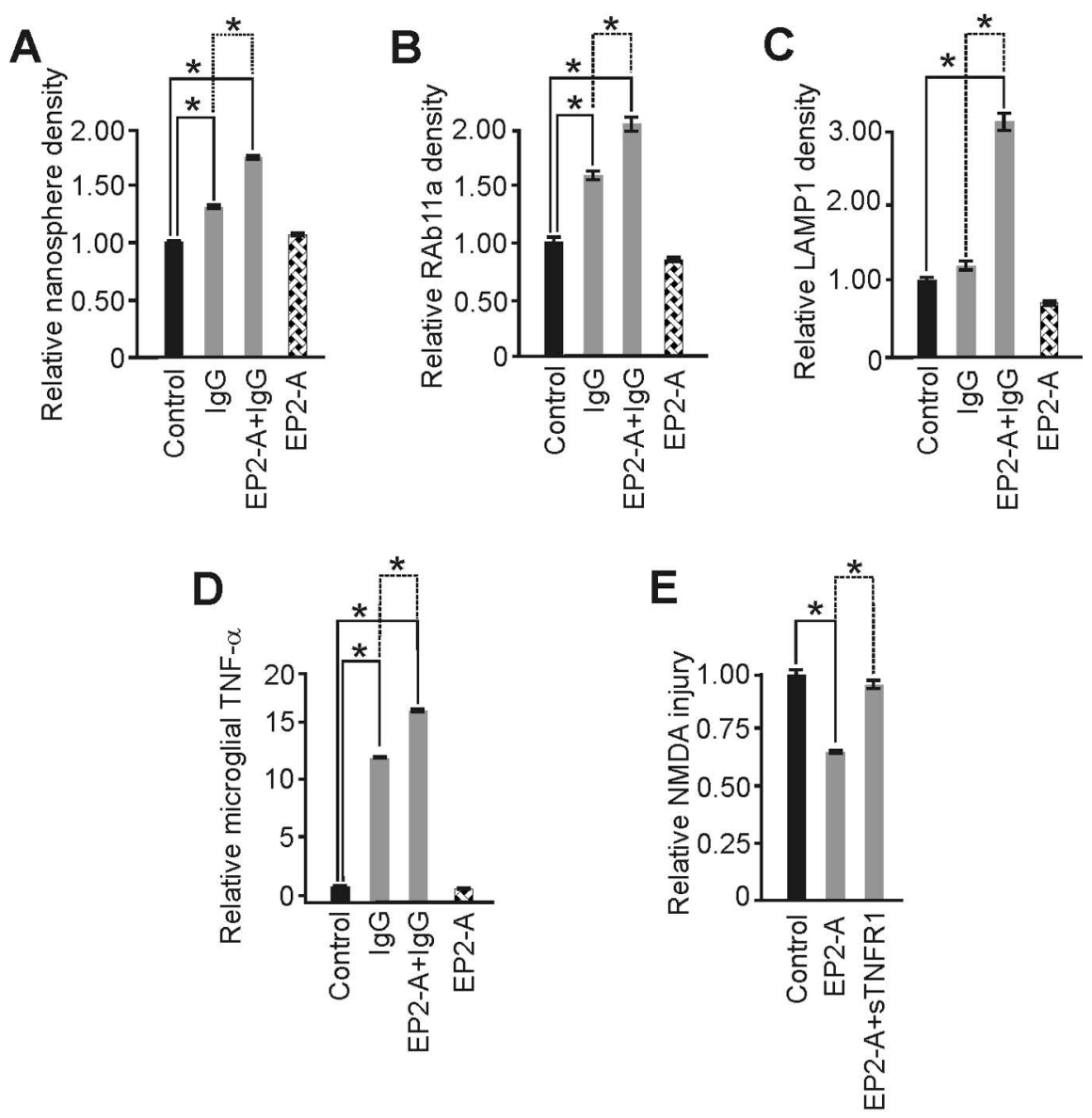

Figure 8. Prostaglandin E2 receptor subtype activation (EP2-A) amplified IgG-induced microglia activation and triggered neuroprotection dependent on TNF- $\alpha$. Butaprost, an EP2 receptor agonist, was used as a surrogate of PGE, release from increased neuronal activity to begin exploring whether paracrine signaling from neuronal activity might influence microglial recycling endocytosis and TNF- $\alpha$ change from neuroprotective $\lg G$. $A$, IgG significantly increased endocytosis from control and this change was further and significantly enhanced by coincubation with EP2-A, whereas EP2-A exposure alone had no impact. $\boldsymbol{B}$, Recycling endocytosis, measured via RAb11a immunostaining, showed a similar significant increase by lgG over control that was significantly enhanced by inclusion of EP2-A. Again, EP2-A alone had no impact. C, Furthermore, lgG did not prompt a change in late endosome/early lysosome trafficking, measured via LAMP1 immunostaining. However, inclusion of EP2-A triggered the trend increase from lgG alone to a significant increase, consistent with the change seen from high [i.e., $2000 \mu \mathrm{g} / \mathrm{ml}$ (Fig. 3)] lgG alone, further suggesting that prostaglandins can amplify monomeric lgG-mediated endocytotic vesicle trafficking. $\boldsymbol{D}$, Production of TNF- $\alpha$ from primary microglia further supported this conclusion. IgG exposure alone prompted a significant increase in TNF- $\alpha$ production that was further significantly ( $p=0.01$ ) amplified by EP2-A. Here, however, the amplification of cytokine secretion is tied to recycling endocytosis (and not lysosomal trafficking) because high dose lgG alone, which enhanced ED-1 (Fig. 2) and LAMP1 immunostaining (Fig. 3), did not trigger a significant increase in TNF- $\alpha$ (Fig. 4). $\boldsymbol{E}$, Neuroprotection from EP2-A is caused by TNF- $\alpha$ because abrogation of signaling from this innate cytokine via sTNFR1 removed the neuroprotective effect to a level of injury significantly greater than with EP2-A alone. [Specific significant " $p$ " values (unless otherwise noted above) were $(\boldsymbol{A}) p<$ $0.001 ; \alpha=1.00$ with relative levels of $1.34 \pm 0.03$ ( $n=182$ cells), $1.71 \pm 0.03(n=262)$, and $1.06 \pm 0.03(n=147)$ vs control $(1.00 \pm 0.01 ; n=686) ;(B) p<0.001 ; \alpha=1.00$ with relative levels of $1.56 \pm 0.09$ ( $n=135$ cells), $2.06 \pm 0.13(n=110)$, and $0.79 \pm 0.03(n=160)$ vs control $(1.00 \pm 0.09 ; n=168) ;(C) p<0.001 ; \alpha=1.00$ with relative levels of $1.19 \pm 0.12(n=33$ cells), $3.12 \pm 0.29(n=73)$, and $0.60 \pm 0.08$ ( $n=47)$ vs control $(1.00 \pm 0.07 ; n=67) ;(D) p<0.001 ; \alpha=1.00$ with relative levels of $11.90 \pm 1.3,16.00 \pm 1.69$, and $0.69 \pm 0.04$ vs control $(1.00 \pm 0.04)$ and $n=9 /$ group; $(\boldsymbol{E}) p<0.001 ; \alpha=1.00$ with relative injury levels of $0.64 \pm 0.02(n=8)$ and $0.95 \pm 0.03(n=7)$ vs control $(1.00 \pm 0.03 ; n=7)]$. Data represent mean \pm SEM and significance $\left({ }^{*} p<0.05\right)$.

Minocycline provided additional evidence that IgG-mediated physiological effects can be modulated by pharmacological maneuvers. Minocycline is an anti-inflammatory agent and retards microglial inflammatory change and related injury after the onset of neurological disease (Tikka et al., 2001; Lai and Todd, 2006). Importantly, minocycline abrogated neuroprotection at physiological IgG doses and the related transformation of microglia to reactive species as evidenced by recycling endocytosis and related TNF- $\alpha$ production. Minocycline also prevents microglial activa- tion and learning from environmental enrichment (Ziv et al., 2006). Thus, our findings and this literature further support the notion that proinflammatory changes unassociated with disease involving microglial activation (Streit, 2002) can be nutritive (Hadley, 2003).

The mechanisms responsible for these minocycline effects are unknown. However, some insights can be gleaned from the published literature. Minocycline inhibits PARP-1 [poly(ADP-ribose) polymerase-1] which is activated by DNA damage (Alano et al., 2006). However, although this potential mechanism might play a role in reducing injury after the onset of disease, it is unclear how such inhibition would remove neuroprotection (e.g., from monomeric $\operatorname{IgG}$ ) before disease onset. Instead, signaling modifications downstream of receptor mediated endocytosis may be involved. For example, receptor mediated recycling endocytosis of transferrin receptors activates extracellular signal kinase $1 / 2$ and p38 mitogenactivated protein kinase (Calzolari et al., 2006), pathways that might be similarly activated by microglial recycling endocytosis of IgG. Extracellular signal kinase 1/2 and p38 mitogen-activated protein kinase are involved TNF- $\alpha$ expression (Oppenheim and Feldmann, 2001) and minocycline inhibits p38 mitogen-activated kinase (Alano et al., 2006). IgG-receptor downstream signaling amplification involved in TNF- $\alpha$ expression from primary microglia may explain how small increases in low levels of added IgG produced significant but small increases in recycling endocytosis (Fig. $3 G$ ) and significant and large changes in TNF- $\alpha$ (Fig. 4A). In addition, minocycline inhibits TNF- $\alpha$ production from microglia without inhibiting phagocytosis of amyloid $\beta$ (Familian et al., 2007). This is consistent with our data that shows minocycline can dissociate physiological IgG-mediated endocytosis and related TNF- $\alpha$ production (Fig. 7). Why minocycline alone did not affect primary microglial production of TNF- $\alpha$ but significantly inhibited TNF- $\alpha$ production from microglia in slice cultures is unclear. Such differential effects may stem from the impact of minocycline on other cell types in slice cultures that influence microglial function.

There is increasing new recognition of the concept that a toxin brought below threshold can become a nutrient. For example, this concept is a central tenet of ischemic preconditioning where stimuli associated with increased neural cell death after the onset of injury become nutritive when they are only "irritants" before the onset of disease (Dirnagl et al., 2003). Our data begin to indicate that intrinsic brain signaling (e.g., via $\operatorname{IgG}$ ) can be a stimulus that functions in this same way. The U-shaped dose- 
responses for IgG-mediated neuroprotection and microglial activation (i.e., increased recycling endocytosis and TNF- $\alpha$ production) follow a pattern termed hormesis or "... a dose-response relationship phenomenon characterized by low-dose stimulation and high dose inhibition" (Calabrese and Baldwin, 2003; Hadley, 2003). Interestingly, this same response pattern is also seen with drug treatments for stroke (Calabrese, 2008). High TNF- $\alpha$ concentrations increase ischemic injury when administered into brain a day before focal ischemia (Barone et al., 1997). Alternatively, like others (Wilde et al. 2000), we showed that low concentration TNF- $\alpha$ is neuroprotective and can be elevated by monomeric IgG, perhaps via neuronal activity, to low and nutritive levels. Together, our results begin to suggest unexpected mechanisms by which brain functions can converge to result in increased TNF- $\alpha$ production.

In summary, our studies show that monomeric IgG has signaling functions in uninjured brain involving adaptive, proinflammatory changes that, rather than accompanying injury, result in neuroprotection over time, which may be amplified by $\mathrm{PGE}_{2}$. Microglial IgG-related recycling endocytosis and associated production of TNF- $\alpha$ are previously unrecognized targets for deciphering the bases of activity-dependent neuroprotection.

\section{References}

Alano CC, Kauppinen TM, Valls VA, Swanson RA (2006) Minocycline inhibits poly(ADP-ribose) polymerase-1 at nanomolar concentrations. Proc Natl Acad Sci U S A 103:9685-9690.

Ang AL, Taguchi T, Francis S, Fölsch H, Murrells LJ, Pypaert M, Warren G, Mallman I (2004) Recycling endosomes can serve as intermediates during transport from the golgi to the plasma membrane of MDCK cells. J Cell Biol 167:531-543.

Arumugam TV, Tang SC, Lathia JD, Cheng A, Mughal MR, Chigurupati S, Magnus T, Chan SL, Jo DG, Ouyang X, Fairlie DP, Granger DN, Vortmeyer A, Basta M, Mattson MP (2007) Intravenous immunoglobin (IVIG) protects the brain against experimental stroke by preventing complement-mediated neuronal cell death. Proc Natl Acad Sci U S A 104:14104-14109.

Barnes N, Gavin AL, Tan PS, Mottram P, Koentgen F, Hogarth PM (2002) FcgammaRI-deficient mice show multiple alterations to inflammatory and immune responses. Immunity 16:379-389.

Barone FC, Arvin B, White RF, Miller A, Webb CL, Willette RN, Lysko PG, Feuerstein GZ (1997) Tumor necrosis factor-alpha. A mediator of focal ischemic brain injury. Stroke 28:1233-1244.

Bauer J, Sminia T, Wouterlood FG, Dijkstra CD (1994) Phagocytic activity of macrophages and microglial cells during the course of chronic relapsing experimental autoimmune encephalomyelitis. J Neurosci Res 38:365-375.

Beattie EC, Stellwagen D, Morishita W, Bresnahan JC, Ha BK, Von Zastrow M, Beattie MS, Malenka RC (2002) Control of synaptic strength by glial TNF $\alpha$. Science 295:2282-2285.

Bondarenko A, Chesler M (2001) Rapid astrocyte death induced by transient hypoxia, acidosis and extracellular ion shifts. Glia 34:134-142.

Boulanger LM, Shatz CJ (2004) Immune signaling in neural development, synaptic plasticity and disease. Nat Rev Neurosci 5:521-531.

Brewer GJ, Torricelli JR, Evege EK, Price PJ (1993) Optimized survival of hippocampal neurons in B27-supplemented Neurobasal, a new serumfree medium combination. J Neurosci Res 35:567-576.

Burbach GJ, Dehn D, Del Turco D, Staufenbiel M, Deller T (2004) Laser microdissection reveals regional and cellular differences in GFAP mRNA upregulation following brain injury, axonal denervation, and amyloid plaque deposition. Glia 48:76-84.

Caggiano AO, Kraig RP (1999) Prostaglandin E receptor subtypes in cultured rat microglia and their role in reducing lipopolysaccharide-induced interleukin-1beta production. J Neurochem 72:565-575.

Calabrese EJ (2008) Drug therapies for stroke and traumatic brain injury often display U-shaped dose responses: occurrence, mechanisms, and clinical implications. Crit Rev Toxicol 38:557-577.

Calabrese EJ, Baldwin LA (2003) Hormesis: The dose-response revolution. Annu Rev Pharmacol Toxicol 43:175-197.
Calzolari A, Raggi C, Deaglio S, Sposi NM, Stafsnes M, Fecchi K, Parolini I, Malavasi F, Peschle C, Sargiacomo M, Testa U (2006) TfR2 localizes in lipid raft domains and is released in exosomes to activate signal transduction along the MAPK pathway. J Cell Sci 119:4486-4498.

Cserr HF (1974) Relationship between cerebrospinal fluid and interstitial fluid of brain. Fed Proc 33:2075-2080.

de Bock F, Derijard B, Dornand J, Bockaert J, Rondouin G (1998) The neuronal death induced by endotoxic shock but not that induced by excitatory amino acids requires TNF-alpha. Eur J Neurosci 10:3107-3114.

Diemel RV, ter Hart GJ, Derksen GJ, Koenderman AHL, Aalberse RC (2005) Characterization of immunoglobulin $\mathrm{G}$ fragments in liquid intravenous immunoglobulin products. Transfusion 45:1601-1609.

Dirnagl U, Simon RP, Hallenbeck JM (2003) Ischemic tolerance and endogenous neuroprotection. Trends Neurosci 26:248-254.

Dorrington KJ, Tanford C (1970) Molecular size and conformation of immunoglobins. Adv Immunol 12:333-381.

Familian A, Eikelenboom P, Veerhuis R (2007) Minocycline does not affect amyloid beta phagocytosis by human microglial cells. Neurosci Lett 416:87-91.

Fergusson D, Hutton B, Sharma M, Tinmouth A, Wilson K, Cameron DW, Hebert PC (2005) Use of intravenous immunoglobin for treatment of neurologic conditions: a systematic review. Transfusion 45:1640-1657.

Gáborik Z, Hunyady L (2004) Intracellular trafficking of hormone receptors. Trends Endocrinol Metab 15:286-293.

Gao B, Tsan MF (2003) Endotoxin contamination in recombinant human heat shock protein 70 (HSP70) preparation is responsible for the induction of tumor necrosis factor $\alpha$ release by murine macrophages. J Biol Chem 278:174-179.

Gessner JE, Heiken H, Tamm A, Schmidt RE (1998) The IgG Fc receptor family. Ann Hematol 76:231-248.

Gregersen R, Lambertsen K, Finsen B (2000) Microglia and macrophages are the major source of tumor necrosis factor in permanent middle cerebral artery occlusion in mice. J Cereb Blood Flow Metab 20:53-65.

Hadley C (2003) What doesn't kill you will make you stronger. A new model for risk assessment may not only revolutionize the field of toxicology, but also have vast implications for risk assessment. EMBO Rep 4:924-926.

Harrison PT, Davis W, Norman JC, Hockaday AR, Allen JM (1994) Binding of monomeric immunoglobin G triggers Fc $\gamma$ RI-mediated endocytosis. J Biol Chem 269:24396-24402.

Howard CV, Reed MG (1998) Unbiased stereology: three-dimensional measurement in microscopy. New York: Springer.

Huh GS, Boulanger LM, Du H, Riquelme PA, Brotz TM, Shatz CJ (2000) Functional requirements for class I MHC in CNS development and plasticity. Science 290:2155-2159.

Hulse RE, Kunkler PE, Fedynyshyn JP, Kraig RP (2004) Optimization of multiplexed bead-based cytokine immunoassay for rat serum and brain tissue. J Neurosci Methods 136:87-98.

Hulse RE, Kunkler PE, Kraig RP (2006) Physiological IgG is neuroprotective via TNF- $\alpha$ from activated microglia. Soc Neurosci Abstr 32:87.6.

Kaneko M, Stellwagen D, Malenka RC, Stryker MP (2008) Tumor necrosis factor- $\alpha$ mediates one component of competitive, experience-dependent plasticity in developing visual cortex. Neuron 58:673-680.

Kariko K, Weissman KK, Welsh FA (2004) Inhibition of toll-receptor and cytokine signaling - a unifying theme in ischemic tolerance. J Cereb Blood Flow Metab 24:1288-1304.

Kennedy PG, Lisak RP, Raff MC (1980) Cell type-specific markers for human glial and neuronal cells in culture. Lab Invest 43:342-351.

Kraig RP, Hulse RE, Kunkler PE, Langan G (2003) Environmental enrichment (EE) may be neuroprotective by modulating synaptic activity (SA) via pro- and anti-inflammatory mediators (IMS). Soc Neurosci Abstr 29:737.15.

Kraig RP, Hulse RE, Kunkler PE (2005) Spreading depression (SD)-induced neuroprotection depends on TNF- $\alpha$. Soc Neurosci Abstr 31:97.12.

Kraig RP, Hulse RE, Kunkler PE (2006) LTP-induced neuroprotection depends on TNF- $\alpha$. Soc Neurosci Abstr 32:87.4.

Kraig RP, Hulse RE, Swenson W (2007) Neuroprotection from prostaglandin (PGE) receptor subtype (EP2) activation involves TNF- $\alpha$ and enhanced microglial recycling endocytosis (MRE). Soc Neurosci Abstr 33:598.9.

Kunkler PE, Kraig RP (1997) Reactive astrocytosis from excitotoxic injury in hippocampal organ culture parallels that seen in vivo. J Cereb Blood Flow Metab 17:26-43. 
Kunkler PE, Hulse RE, Kraig RP (2004) Multiplexed cytokine protein expression profiles from spreading depression in hippocampal organotypic cultures. J Cereb Blood Flow Metab 24:828-839.

Kunkler PE, Hulse RE, Schmitt MW, Nicholson C, Kraig RP (2005) Optical current source density analysis in hippocampal organotypic culture shows that spreading depression occurs with uniquely reversing currents. J Neurosci 25:3952-3961.

Lai AY, Todd KG (2006) Hypoxia-activated microglial mediators of neuronal survival are differentially regulated by tetracyclines. Glia 53:809-816.

Lanzavecchia A (1983) One out of five peripheral blood B lymphocytes is activated to high-rate Ig production by human alloreactive $\mathrm{T}$ cell clones. Eur J Immunol 13:820-824.

Lee SC, Liu W, Dickson DW, Brosnan CF, Berman JW (1993) Cytokine production by human fetal microglia and astrocytes. J Immunol 150:2659-2667.

Lewis V, Green SA, Marsh M, Vihko P, Helenius A, Mellman I (1985) Glycoproteins of the lysosomal membrane. J Cell Biol 100:1839-1847.

Mascher B, Schlenke P, Seyfarth M (1999) Expression and kinetics of cytokines determined by intracellular staining using flow cytometry. J Immunol Methods 223:115-121.

Maxfield FR, McGraw TE (2004) Endocytotic recycling. Nat Rev Mol Cell Biol 5:121-132.

McCullough L, Wu L, Haughey N, Liang X, Hand T, Wang Q, Breyer RM, Andreasson K (2004) Neuroprotective function of the $\mathrm{PGE}_{2}$ EP2 receptor in cerebral ischemia. J Neurosci 24:257-268.

Mellman I, Plutner H, Ukkonen P (1984) Internalization and rapid recycling of macrophage Fc receptors tagged with monovalent antireceptor antibody: possible role in prelysosomal compartment. J Cell Biol 98:1163-1169.

Mukherjee S, Ghosh RN, Maxfield FR (1997) Endocytosis. Physiol Rev 77:759-803.

Murray RZ, Kay JG, Sangermani DG, Stow JL (2005) A role for the phagosome in cytokine secretion. Science 310:1492-1495.

Naka F, Narita N, Okado N, Narita M (2005) Modification of AMPA receptor properties following environmental enrichment. Brain Dev 27:275-278.

Nedergaard M, Hansen AJ (1988) Spreading depression is not associated with neuronal injury in the normal brain. Brain Res 449:395-398.

Newell DW, Barth A, Papermaster V, Malouf AT (1995) Glutamate and non-glutamate receptor mediated toxicity caused by oxygen and glucose deprivation in organotypic hippocampal cultures. J Neurosci 15:7702-7711.

Neumann H, Schmidt H, Cavalié A, Jenne D, Wekerle H (1997) Major histocompatibility complex (MHC) class I gene expression in single neurons of the central nervous system: differential regulation by interferon (IFN)gamma and tumor necrosis factor (TNF)-alpha. J Exp Med 185:305-316.

Nimmerjahn F, Ravetch JV (2006) Fc $\gamma$ receptors: Old friends and new family members. Immunity 24:19-28.

Oppenheim JJ, Feldmann M (2001) Introduction to the role of cytokines in innate host defense and adaptive immunity. In: Cytokine Reference, Vol 1 (Oppenheim JJ, Feldmann M, eds), pp 3-20. New York: Academic.

Pandey KN (2005) Internalization and trafficking of guanylyl cyclase/natiuretic peptide receptor-A. Peptides 26:985-1000.
Park M, Penick EC, Edwards JG, Kauer JA, Ehlers MD (2004) Recycling endosomes supply AMPA receptors for LTP. Science 305:1972-1975.

Rosenzweig HL, Lessov NS, Henshall DC, Minami M, Simon RP, StenzelPoore MP (2004) Endotoxin preconditioning prevents cellular inflammatory response during ischemic neuroprotection in mice. Stroke $35: 2576-2581$

Spector W (1956) Handbook of biological data. Philadelphia: Saunders.

Steiner P, Sarria JC, Glauser L, Magnin S, Catsicas S, Hirling H (2002) Modulation of receptor cycling by neuron-enriched endosomal protein of 21 kD. J Cell Biol 157:1197-1209.

Stellwagen D, Malenka RC (2006) Synaptic scaling mediated by glial TNF- $\alpha$. Nature 440:1054-1059.

Streit W (1995) Microglial Cells. In: Neuroglia (Kettenmann H, Ransom BR, eds), pp 85-96. New York: Oxford UP.

Streit WJ (2002) Microglia as neuroprotective, immunocompetent cells of the CNS. Glia 40:133-139.

Stuart L, Ezekowitz RAB (2005) Phagocytosis: elegant complexity. Immunity 22:539-550

Tikka T, Fiebich BL, Goldsteins G, Keinanen R, Koistinaho J (2001) Minocycline, a tetracycline derivative, is neuroprotective against excitotoxicity by inhibiting activation and proliferation of microglia. J Neurosci 21:2580-2588.

Ukkonen P, Lewis V, Marsh M, Helenius A, Mellman I (1986) Transport of macrophage Fc receptors and fc receptor-bound ligands to lysosomes. J Exp Med 163:952-971.

Weissman KK, Welsh FA (2004) Inhibition of toll-receptor and cytokine signaling - a unifying theme in ischemic tolerance. J Cereb Blood Flow Met 24:128-134.

Wainszelbaum MJ, Proctor BM, Pontow SE, Stahl PD, Barbieri A (2006) IL4/PGE 2 induction of an enlarged early endosomal compartment in mouse macrophages is Rab5-depdendent. Exp. Cell Res 312:2238-2251.

Wilde GJ, Pringle AK, Sundstrom LE, Mann DA, Ianotti F (2000) Attenuation and augmentation of ischaemia-related neuronal death by tumour necrosis factor- $\alpha$ in vitro. Eur J Neurosci 12:3863-3870.

Will B, Galani R, Kelche C, Rosenzweig MR (2004) Recovery from brain injury in animals: relative efficacy of environmental enrichment, physical exercise or formal training (1990-2002). Prog Neurobiol 72:167-182.

Wurster U, Haas J (1994) Passage of intravenous immunoglobin and interaction with the CNS. J Neurol Neurosurg Psychiatry 57:21-25.

Yamagata K, Andreasson KI, Kaufman WE, Branes CA, Worley PF (1993) Expression of a mitogen-inducible cyclooxygenase in brain neurons: regulation by synaptic activity and glucocorticoids. Neuron 11:371-386.

Zhang Y, Pardridge WM (2001) Mediated efflux of IgG molecules from brain to blood across the blood-brain barrier. J Neuroimmunol 114:168-172.

Ziv Y, Ron N, Butovsky O, Landa G, Sudai E, Greenberg N, Cohen H, Kipnis J, Schwartz M (2006) Immune cells contribute to the maintenance of neurogenesis and spatial learning abilities in adulthood. Nat Neurosci 9:268-275.

Zou JY, Crews FT (2005) TNF $\alpha$ potentiates glutamate neurotoxicity by inhibiting glutamate uptake in organotypic brain slice cultures: neuroprotection by NF $\kappa$ B inhibition. Brain Res 1034:11-24. 